\title{
Distributions and Community Composition of Birds in Iraq's Central Marsh
}

\author{
Nadheer A. Fazaa, ${ }^{1,2}$ Jonathon C. Dunn, ${ }^{1}$ and Mark J. Whittingham ${ }^{1}$ \\ ${ }^{1}$ School of Biology, Newcastle University, Ridley Building 2, Newcastle upon Tyne NE1 7RU, UK \\ ${ }^{2}$ Department of Biology, College of Science for Women, University of Baghdad, Baghdad, Iraq \\ Correspondence should be addressed to Nadheer A. Fazaa; nadheerabood@gmail.com
}

Received 30 July 2016; Revised 22 December 2016; Accepted 19 January 2017; Published 8 March 2017

Academic Editor: Curtis C. Daehler

Copyright ( 2017 Nadheer A. Fazaa et al. This is an open access article distributed under the Creative Commons Attribution License, which permits unrestricted use, distribution, and reproduction in any medium, provided the original work is properly cited.

\begin{abstract}
The Central Marsh (CM) in southern Iraq is known to provide important habitats for both resident and migrant birds. The CM has been used extensively by humans, in part due to its high levels of productivity and biodiversity. It was drained in the 1990s by the government and reflooded and restored in 2003. Recent brief surveys of the CM from 2005 to 2010 recorded 94 bird species. Our study combined transects and point counts in detailed monthly surveys from October 2013 to June 2014 in the CM. We found a total of 125 bird species in the CM across all surveys, with 31 species recorded for the first time in the CM and 11 species categorised as red listed by the IUCN. Fourteen species were confirmed breeding in the CM. Cluster analysis using NMDS ordination showed that the study area can be divided into three main clusters of bird assemblages which are presented here. We provide management recommendations based on our findings.
\end{abstract}

\section{Introduction}

The Iraqi Central Marsh (CM) is a globally important open water and freshwater marsh [1] located between three provinces (Missan: $31^{\circ} 10^{\prime} \mathrm{N}, 47^{\circ} 05 \mathrm{E}$; Thi-Qar: $30^{\circ} 50^{\prime} \mathrm{N}$ to $31^{\circ} 30^{\prime} \mathrm{N}$; and Basra: $46^{\circ} 45^{\prime} \mathrm{E}$ to $46^{\circ} 25^{\prime} \mathrm{E}$ ) in the south of Iraq [2]. The CM is almost 300,000 ha in area and is part of a larger marshland complex [3]. The CM has always been used extensively by humans, in part due to its high levels of productivity and biodiversity [4]. The CM has long been known to provide important permanent habitat for large number of birds and is part of a flyway for thousands more migrating between Siberia and Africa [5, 6]. Eighty bird species were found in the CM in the last complete census in the 1970s [6] and the area was identified as one of 42 Iraqi Important Bird and Biodiversity Areas (IBAs) [3]. Despite its importance for both people and wildlife, the CM was totally drained in the 1990s by the government, which caused huge levels of biodiversity loss and the disappearance of nearly all bird species from the area [7]. The motivation for this drainage is not clear, with some sources stating political motivation [1] and others agricultural expansion, which had already begun in the 1970s [8].
Parts of the CM were reflooded and restored in 2003 using the River Euphrates water to feed the CM directly, resulting in a huge reverse migration of both local people and bird species $[9,10]$. Concomitantly, there was a change in governmental attitudes and NGOs toward wildlife and the value of birds, especially regarding the maintenance of healthy ecosystem functioning [11]. Reflecting this change, 141,615 ha $(47 \%)$ of the CM was declared as the country's first national park (NP) in 2013 (Mesopotamian National Park or MNP) $[12,13]$ and the CM was identified as one of 82 Iraqi Key Biodiversity Areas (KBAs), based largely on bird data collected between 2005 and 2008 [2]. While the difficult political situation in Iraq made it impossible to conduct bird surveys between 1980 and 2003 [1], the KBA assessment showed that bird species in the CM have begun to recover to predrainage levels (94 species recorded [4]). However, many of these surveys were rapid (visiting the area for one day in the season) (seasonal surveys were conducted between 2005 and 2010 by Nature Iraq (NI) and the Iraqi Ministry of Environment) and therefore need updating to better understand the conservation statuses of CM birds. Furthermore, the KBA assessment did not explicitly examine 

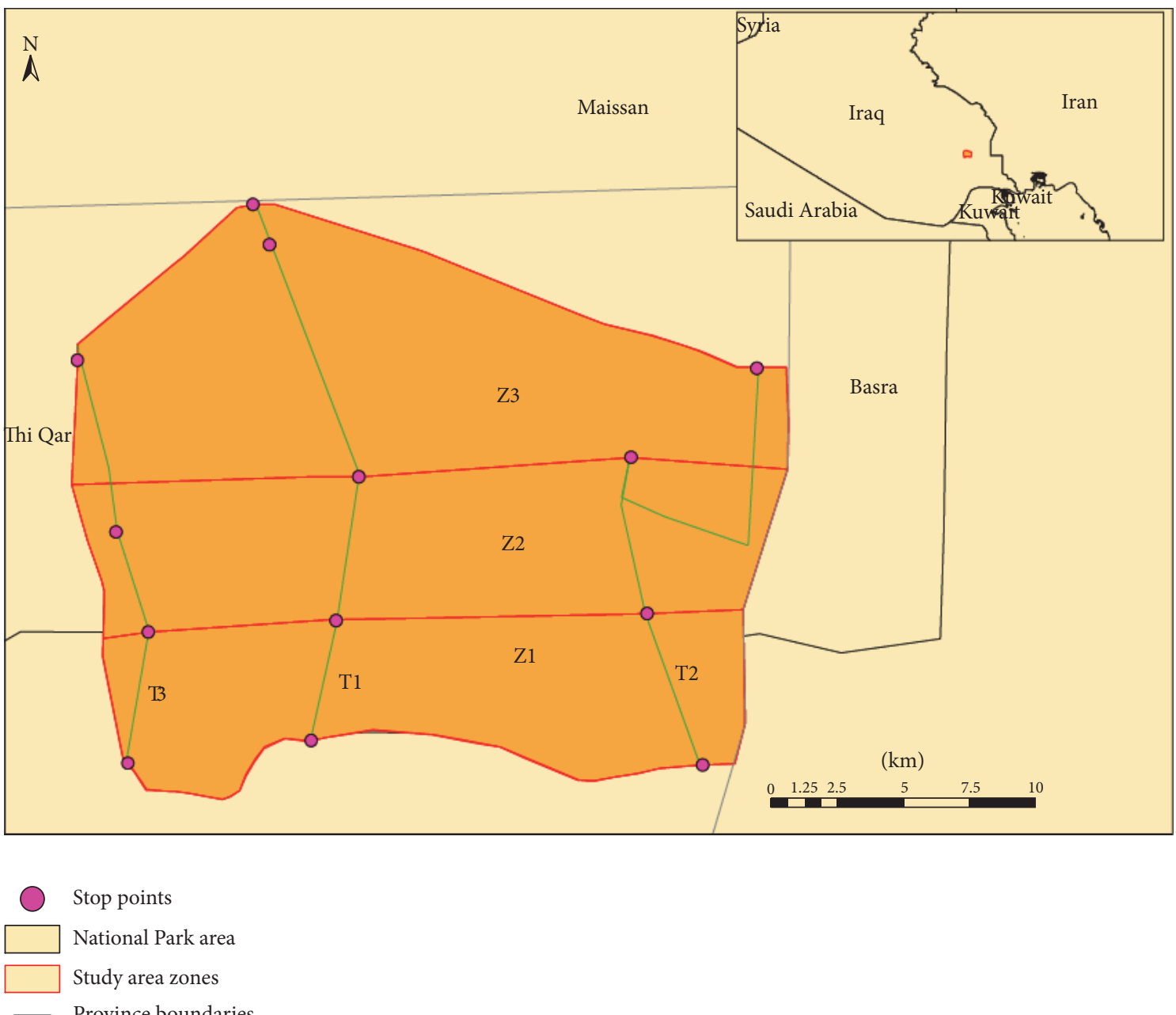

FIGURE 1: Area of study in the CM showing locations of transect surveys (T1: transect 1, T2: transect 2, and T3: transect 3) and the location of the CM within the Middle East within the overview map (as shown in orange).

the distributions or habitat associations of birds within the $\mathrm{CM}$, treating the whole area as one conservation unit $[4,10]$. Treating the whole of the CM in this way could hinder attempts to restore the CM's bird populations, as many of the significant threats that face birds in the CM are not distributed equally in space [7]. Here we present data from surveys across a nine-month period in 2013-2014.

Our study had three objectives: (i) to provide an inventory of bird species occurring in the CM; (ii) to investigate the spatial and temporal patterns of bird abundance and diversity across the CM; (iii) to describe bird assemblages within different areas of the CM. We use our findings to suggest management actions in the CM to benefit birds.

\section{Methods}

2.1. Study Site and Sampling Protocol. Three longitudinal water transects (each $30 \mathrm{~km}$ in length) were chosen inside the CM to identify and count birds in the marsh from both sides of transects [14]. These three transects ran approximately north-south and followed existing water courses, thus causing only minor disturbance to habitats whilst surveying (Figure 1). The area has historically been supplied with water from the north by the Tigress River. The Euphrates River crosses Chibayish City from the West to the East towards Modina City in Basra province [11]. The Euphrates River has been closed using soil embankments between Chibayish City and Modina City due to the scarcity of water in the river. Therefore, all water coming from the West of Iraq in the Euphrates River now goes directly to the CM.

To aid management, we subdivided the study area into three zones. We did this based on the dominant type of vegetation and similarities in the type of human activity that occurred in each zone (e.g., fishing, reed cutting, and the intensity of water buffalo used for distributing water buffalo milk). This classification was made by visual inspection of the CM and was descriptive only (based on qualitative impressions made during the survey work). Zone one started from the south in the Euphrates River and crossed Chibayish City, with zones two and three extending north inside the national park (Figure 1). Zone one had the most human activity, grazing by water buffalo, and dominance of the plant 
species Typha domingensis. Zone two had intermediary levels of human activity and water buffalo grazing with Typha domingensis and Phragmites australis the dominant plant species, and zone three had the least amount of human activity and grazing with Phragmites australis the dominant plant species.

Nine surveys were carried out in the CM from October 2013 to June 2014 (for exact dates see Appendix). A motor canoe was for transport, with surveys starting from the riverside in the south of the national park and finishing in the north. Three days were spent in the area for each survey (one day/transect), and six-eight hours per day were spent moving along each transect. All field observations were conducted by the same observer and were started from the river in zone one in the morning and finished in the afternoon at the end of zone three (05:30-12:30/13:30 in the summer, and 07:0014:00/15:00 in the winter). The stop points (point counts) are shown in Figure 1; time spent at each stop was 30-40 minutes (the survey included water and sediment sampling; therefore, almost 15-20 minutes were spent for bird records in each point). Our chosen survey time for bird counts was designed to maximise our chances of detecting as many cryptic species as possible, while minimising our chances of doublecounting. Additionally, our sampling design was constrained by safety considerations and logistical difficulties, which, although making it impossible to conduct sampling in zone three in the morning, reduced our risk of double-counting further. A Canon 7D camera with Sigma lens $135 \times 400$ and Canon lens $100 \times 400$ and $8 \times 42$ binoculars were used to observe and count birds in the CM. No observations and counts were undertaken on the way back, apart from new species that were not recorded in the main survey. A Garmin GPS device was used to map the three transects digitally. We used official data from the Iraqi Ministry of Water Resources, Chibayish Branch, to record the monthly water level in the Euphrates River during the survey period.

2.2. Analysis of Species Richness and Abundance and Community Composition. To investigate the role of management zone, month (coded as Julian day), and transect in species richness and abundance, we used general linear models with a Gaussian error structure as our models with a Poisson, quasi-Poisson, and negative binomial error structure were severely overdispersed. To produce acceptable model residual plots, species abundance was square-root transformed but species richness was left untransformed. For each dependent variable, we constructed a full model and used a multimodel inference approach to define the relative importance of each independent variable, as recommended by Burnham and Anderson (2002) [15] and Grueber et al. (2011) [16]. We used the package "MuMIn" [17] to produce all possible candidate models, which were ranked by AICc. We then used model averaging across the full set of candidate models to produce parameter estimates and measures of the relative importance of each parameter [15].

Nonmetric Multidimensional Scaling (NMDS) ordination was conducted using the FactoMine R package [15] in $\mathrm{R}$ to identify whether there were differences in community composition between different management zones. To do this, nine different sites were identified based on the point where each of the three transects intersected each of the three management zones (see Figure 1). The rationale behind splitting up the zones further for this analysis was in response to preliminary analysis of our field observations, which suggested that there were distinct bird communities at finer scales than the three management zones that we originally identified. Then, a Bray-Curtis dissimilarity matrix and dendrogram were created to identify clusters of sites in the CM that were most similar in their bird species' communities (based on both species' identities and abundance). These clusters were then overlaid on the results of the ordination to help identify parts of the $\mathrm{CM}$ with similar bird communities. We chose to use both a dendrogram and NMDS ordination to identify clusters to ensure that our results were robust. All data manipulation and statistical analysis were undertaken in $\mathrm{R}$ version 3.1.3 (R Development Core Team 2015).

\section{Results}

\subsection{Which Bird Species Occur and Breed in the CM and Which Species Are of Conservation Concern?}

3.1.1. Site Importance. A total of 125 bird species were recorded in the CM across all the surveys: 29 were resident species (recorded across all seasons of the survey); 87 were winter visitors and passage migrants; 9 species were noted as summering (Table 4). A total of 31 species were recorded for the first time in the CM. Notable records included (i) White Tailed Eagle (Haliaeetus albicilla), which was recorded in the December survey in transect two, zone two; this species has not been recorded in the CM for more than 40 years; (ii) Fourteen species which were confirmed breeding in the $\mathrm{CM}$ according to the BTO breeding evidence criteria (Little Grebe Tachybaptus ruficollis, Little Bittern Ixobrychus minutus, Squacco Heron Ardeola ralloides, Red-Wattled Lapwing Vanellus indicus, White-Tailed Lapwing Vanellus leucurus, Whiskered Tern Chlidonias hybrida, Eurasian Collared Dove Streptopelia decaocto, Pied Kingfisher Ceryle rudis, Basra Reed Warbler Acrocephalus griseldis, Great Reed Warbler Acrocephalus arundinaceus, Graceful Prinia Prinia gracilis, Iraq Babbler Turdoides altirostris, Purple Swamphen Porphyrio porphyrio, and House Sparrow Passer domesticus; see Table 1 for detailed information about breeding status and more details in the Appendix).

3.1.2. Important Bird Species for Conservation. The survey found 11 species that are important conservation priorities in the CM and are red listed by the IUCN (Table 2), and two endemic species (Basra Reed Warbler and Iraq Babbler), and three near endemic species (Black Francolin, Little Grebe, and Mesopotamian Crow) according to [18]. In addition, there are two species that are regionally threatened (Pygmy Cormorant and Sacred Ibis) and four species that are regionally near threatened (Grey Heron, Purple Heron, Western Marsh Harrier, and Common Kingfisher) in the Arabian Peninsula [19].

3.2. Spatial Distribution of Bird Abundance and Diversity across the CM. According to the raw data from the study 
TABLE 1: Bird breeding statuses in the CM for April-June 2014. Key: $\mathrm{T}=$ transect and $\mathrm{Z}=$ zone.

\begin{tabular}{|c|c|c|}
\hline Month & Species & Description \\
\hline \multirow{6}{*}{ April } & Red-Wattled Lapwing & One nest with two chicks and one egg in T2, Z2 (GPS coordinates: 0706280,3436379 ) \\
\hline & Purple Swamphen & One empty nest T2, Z2 \\
\hline & Graceful Prinia & We did not count the numbers of nests \\
\hline & Warbler & One empty nest in $\mathrm{T} 2, \mathrm{Z} 3$ \\
\hline & House Sparrow & We did not count the numbers of nests \\
\hline & Iraq Babbler & One nest in $\mathrm{T} 1, \mathrm{Z} 2$ \\
\hline \multirow{7}{*}{ May } & Warbler spp. & $\begin{array}{l}\text { (i) Two empty nests of Warbler spp. in T1, Z3 (coordinates: 0683694, 3441836) } \\
\text { (ii) Two nests (with two chicks and one egg in each nest) of Basra Reed Warbler in T2, Z3 } \\
\text { (coordinates: } 0706003,3441503 \text { and } 0705922,3441499 \text { ) }\end{array}$ \\
\hline & Collared Dove & Nest (with two eggs) of Collared Dove in T2, Z1 \\
\hline & Whiskered Tern & $\begin{array}{l}\text { Chicks and large numbers of Whiskered Terns (two colonies; each colony had over } 50 \text { nests) } \\
\text { located in T2, Z3. Each nest was floating on water and all contained three eggs [coordinates: } \\
0705878,344280 \text { and } 0706394,3437954 \text { ]. }\end{array}$ \\
\hline & Little Bittern & Nest of Little Bittern with 4 eggs in transect two [coordinates: 0702287, 3430598]. \\
\hline & White-Tailed Lapwing & $\begin{array}{l}\text { Two nests of White-Tailed Lapwing (one nest with four eggs and second with two eggs) } \\
\text { [coordinates: 0684287, 3434033]. }\end{array}$ \\
\hline & Graceful Prinia & Nest of Graceful Prinia in T3 \\
\hline & House Sparrow & One nest and chicks of House Sparrow in T3 \\
\hline \multirow{7}{*}{ June } & Warbler & $\begin{array}{l}\text { (i) Three nests of Basra Reed Warbler with two chicks and one egg in T1, Z2 [coordinates: } \\
0693162,3436719 \text { and 0684284, 3434030] } \\
\text { (ii) Three nests of Basra Reed Warbler in T2, Z3 [coordinates: 0705880, } 3441550 \text { and 0705874, } \\
\text { 3441525] } \\
\text { (iii) All recorded nests of Basra Reed Warbler in our survey were built on reed stems only } \\
\text { (iv) Basra Reed Warbler shares its preferred reed bed habitat with the similar Great Reed Warbler } \\
\text { (v) Our survey highlighted dominancy of Great Reed Warbler in April (the number of individuals } \\
\text { recorded of Basra Reed Warbler in the area of study was 14, 42, and } 66 \text { and for Great Reed } \\
\text { Warbler was 38, 57, and } 42 \text { in April, May, and June 2014, resp.) }\end{array}$ \\
\hline & Little Bittern & Nest with four eggs and chick of Little Bittern in T2, Z1 [coordinates: 0693170, 3436726] \\
\hline & White Tailed Lapwing & Nest with four eggs of White-Tailed Lapwing in T2, Z1 \\
\hline & Collared Dove & Nest with two eggs of Collared Dove in T2, Z1 \\
\hline & Whiskered Tern & 20 chicks of Whiskered Tern in T2, Z3 \\
\hline & Pied Kingfisher & One chick and 10 eggs of Pied Kingfisher in T1, Z2 \\
\hline & Little Grebe & Observation, 20 juveniles of Little Grebe subspecies Tachybaptus ruficollis iraquensis in T2, Z3 \\
\hline
\end{tabular}

survey, the greatest bird species abundance was in winter (December, January, and February). The areas of the CM with the greatest abundance of birds was along transect two and in zone two. The highest species richness was in January and April along transect one, and in zone two (Figures 2, 3, and 4; see Tables 4, 5, and 7 for further details). We produced a candidate set of eight models based on our full, global model for each response variable. Across all eight species abundance models, zone had relative importance (RI) of
0.92, Julian day had RI of 0.71 , and transect had an RI of 0.09. The model averaged parameter estimates highlighted how zone two had the highest overall species abundance $(\beta=5.74, \mathrm{SE}=1.87)$; however, species abundance did not appear to significantly decline from January to December $(\beta=-0.01, \mathrm{SE}=0.01)$. Across all eight species richness models, zone had relative importance (RI) of 1.00, Julian day had RI of 0.74 , and transect had RI of 0.18 . The model averaged parameter estimates highlighted how zone two had 
TABLE 2: Threatened bird species recorded in the CM by this study (details of numbers recorded are presented in the Appendix).

\begin{tabular}{lcc}
\hline English name & Latin name & Conservation status \\
\hline Marbled Duck & Marmaronetta angustirostris & Vulnerable (IUCN) \\
Basra Reed Warbler & Acrocephalus griseldis & Endangered (IUCN) \\
Greater Spotted Eagle & Aquila clanga & Vulnerable (IUCN) \\
Eastern Imperial Eagle & Aquila heliacal & Vulnerable (IUCN) \\
Ferruginous Duck & Aythya nyroca & Near threatened (IUCN) \\
Cinereous Vulture & Aegypius monachus & Near threatened (IUCN) \\
Pallid Harrier & Circus cyaneus & Near threatened (IUCN) \\
Little Grebe (subspecies) & Near threatened [4] \\
Iraq Babbler & Turdoides altirostris \\
White-Tailed Lapwing & Vanellus leucurus & Least concern (restricted-range) [4] \\
Dead Sea Sparrow & Passer moabiticus & Least concern (Biome-restricted) [4] \\
\hline
\end{tabular}

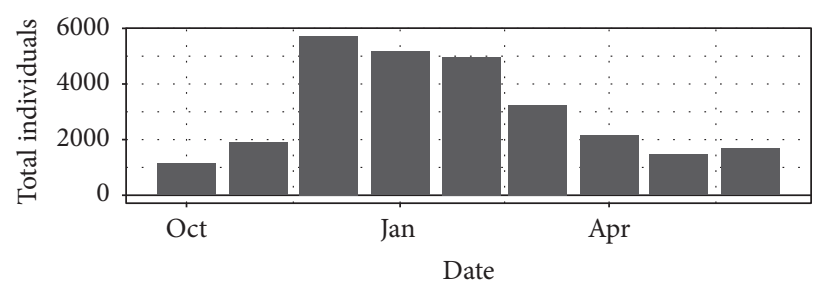

(a)
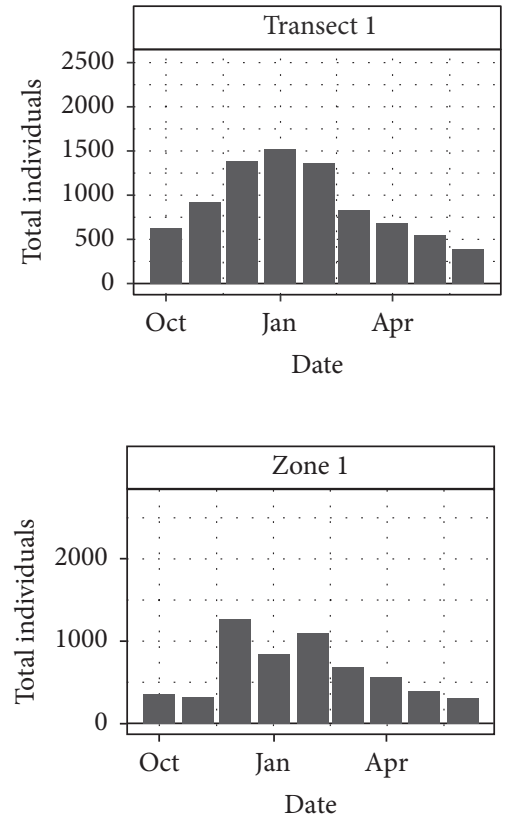

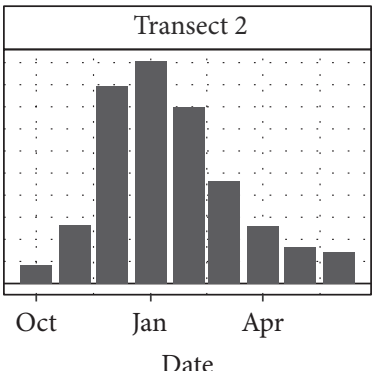

(b)
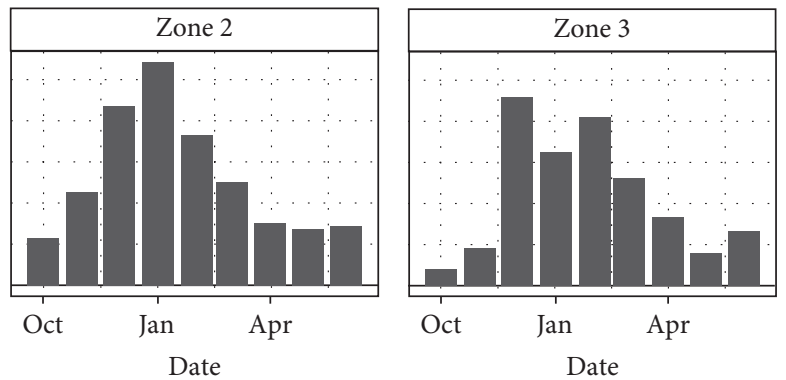

(c)

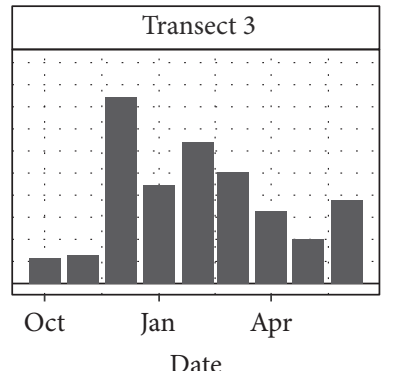

Date

Figure 2: Bird species abundance (all species observations summed) in the Iraqi CM (monthly surveys from October 2013 to June 2014). (a) shows abundance for the whole CM, (b) shows abundance by transect, and (c) shows abundance by zone.

the highest overall species richness $(\beta=9.37, \mathrm{SE}=1.62)$; however, species abundance did not appear to significantly decline from January to December $(\beta=-0.01, \mathrm{SE}=0.01)$.

3.3. What Bird Assemblages Exist within Different Zones in the CM? The dendrogram based on the Bray-Curtis dissimilarity matrix showed that there were at least two main clusters of bird species, with potentially a third cluster in site nine. These results were aligned with the site cluster analysis undertaken using NMDS ordination (the linear fit from a stress plot was $\left.R^{2}=0.98\right)$, which shows that the study area can be categorised into three main clusters of bird species (cluster one $=$ T1-Z1, T1-Z2, T2-Z1, and T3-Z1; cluster 2 = T1-Z3, T2-Z2, T2-Z3, T3-Z2, and T3-Z3; Figures 5 and 6). Some of the 


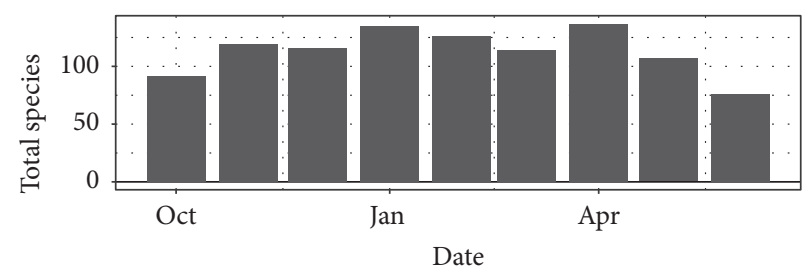

(a)
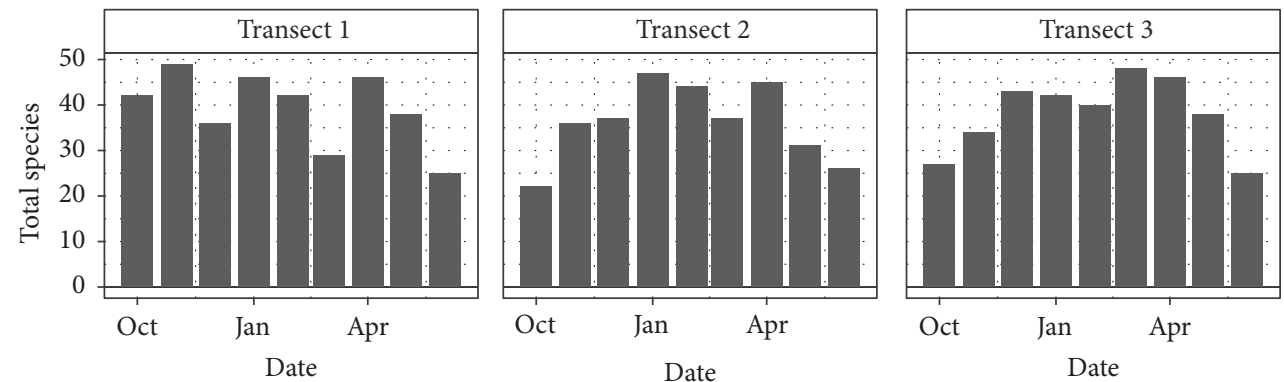

(b)
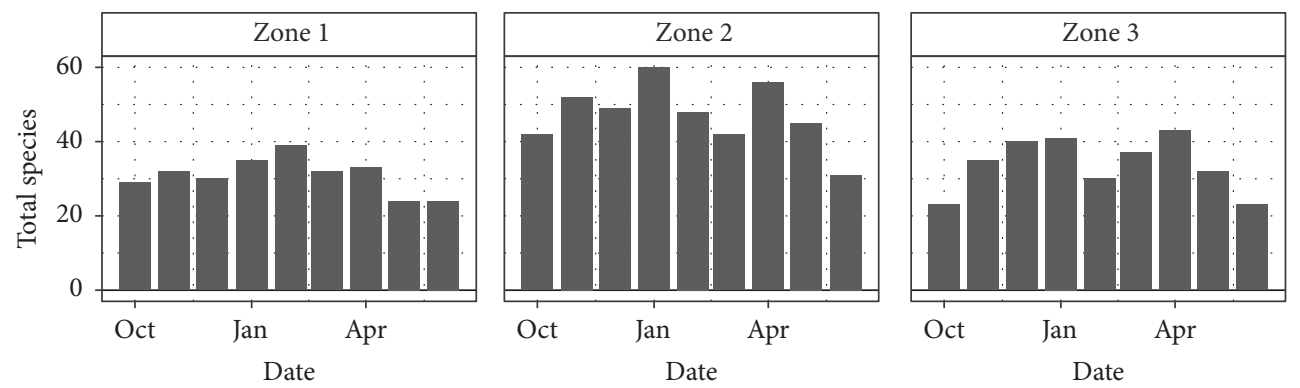

(c)

FIGURE 3: Bird species richness in the Iraqi CM (monthly surveys from October 2013 to June 2014). (a) shows species richness for the whole $\mathrm{CM}$, (b) shows species richness by transect, and (c) shows species richness by zone.

TABle 3: Maximum and minimum monthly water levels in the Euphrates River (Chibayish City station) from October 2013 to June 2014 (official data of the Iraqi Ministry of Water Resources- Chibayish Branch).

\begin{tabular}{lccccccccc}
\hline & October & November & December & January & February & March & April & May & June \\
& 2013 & 2013 & 2013 & 2014 & 2014 & 2014 & 2014 & 2014 & 2014 \\
\hline Min cm & 129 & 147 & 158 & 154 & 176 & 165 & 167 & 165 & 165 \\
Max cm & 148 & 172 & 172 & 179 & 169 & 170 & 172 & 167 & 166 \\
During the survey & 147 & 157 & 160 & 170 & 170 & 165 & 168 & 167 & 166 \\
\hline
\end{tabular}

bird species found in cluster one include Eurasian Bittern (Botaurus stellaris), Cattle Egret (Bubulcus ibis), Moorhen (Gallinula chloropus), Little Tern (Sternula albifrons), Water Pipit (Anthus spinoletta), House Sparrow (Passer domesticus), Cormorant (Phalacrocorax carbo), and Sedge Warbler (Acrocephalus schoenobaenus). We found Common Babbler (Turdoides caudata), Lesser Grey Shrike (Lanius minor), Mallard (Anas platyrhynchos), Armenian Gull (Larus armenicus), Crested Lark (Galerida cristata), Dead Sea Sparrow (Passer moabiticus), and Collared Pratincole (Glareola pratincola) among others within cluster two. Finally, cluster three contained Pallid Harrier (Circus macrourus), Greylag Goose (Anser anser), Grey Heron (Ardea cinerea), and Great White Pelican (Pelecanus onocrotalus).

\section{Discussion}

We recorded 125 bird species in the CM over nine months of survey work, which increased the species list for the area by $24 \%$ and we confirmed the breeding of 14 species and coded 20 species as species observed in breeding season in suitable nesting habitat ( $\mathrm{H}$ according to British Trust for Ornithology breeding status codes). Earlier work over a five-year period recorded 94 species using less intensive survey efforts [4]. Fifty-one breeding bird species were reported by Salim et al. [20] and 77 species were recorded by Salim and Porter [21] in the Iraqi southern marshland complex where the CM is found. In comparison to the wider region at large, 357 bird species were recorded in wetland conservation areas found 


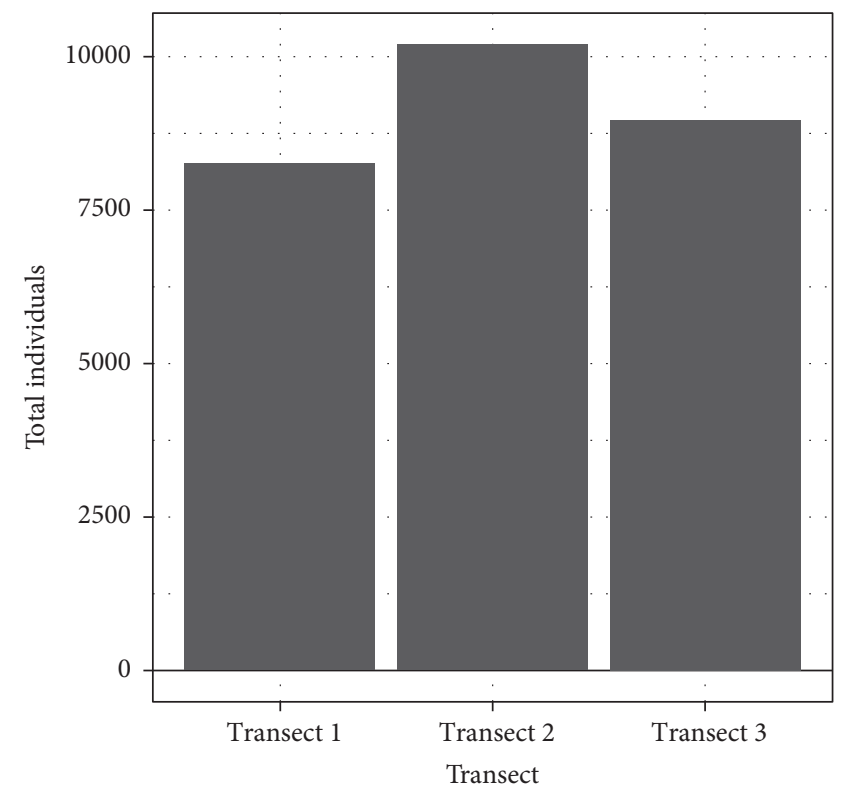

(a)

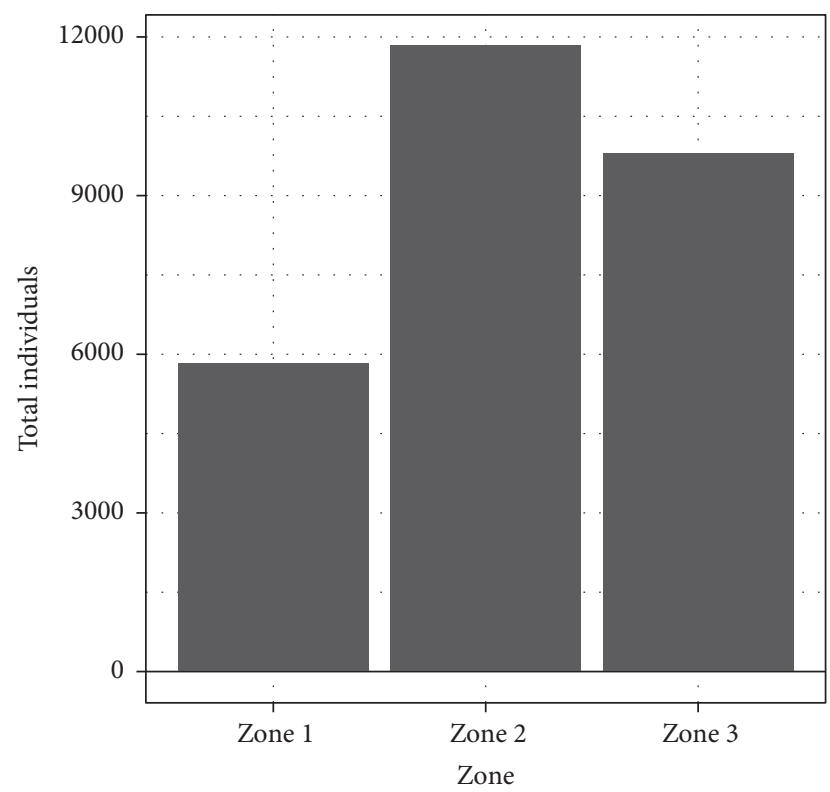

(c)

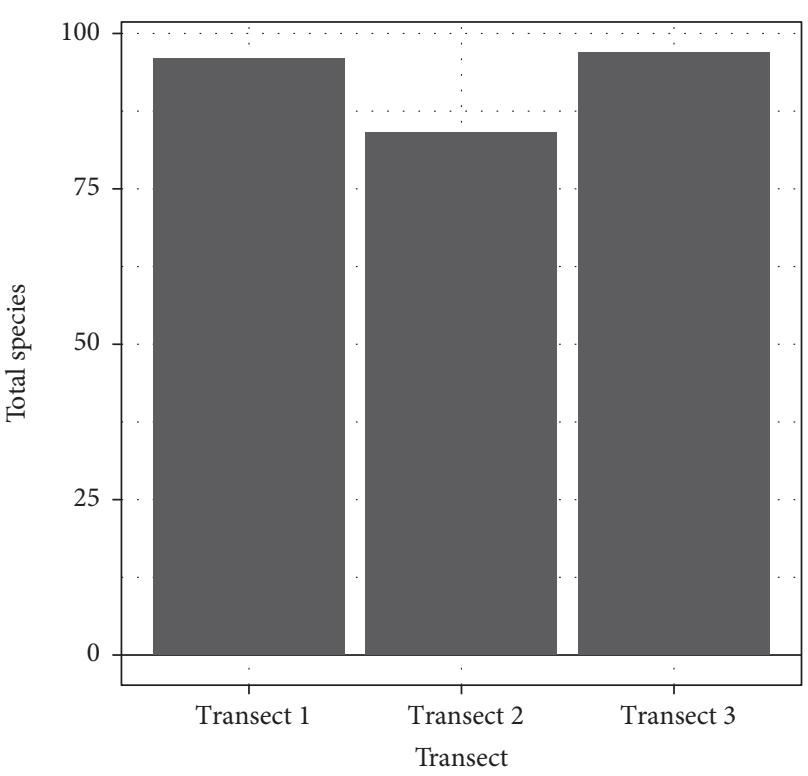

(b)

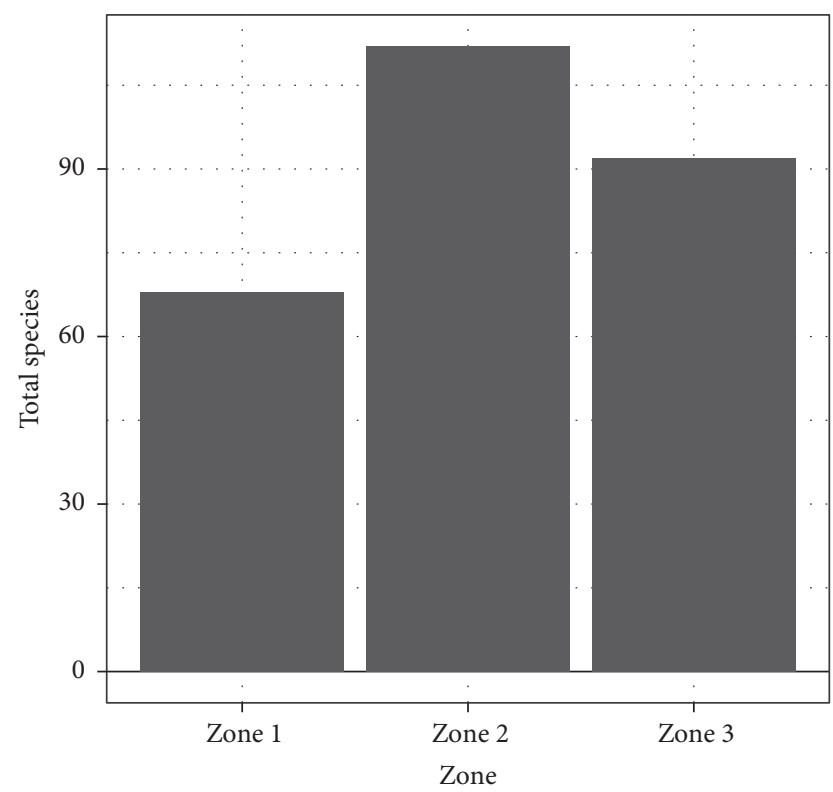

(d)

FIGURE 4: Bird species richness in the Iraqi CM (monthly surveys from October 2013 to June 2014). (a) and (b) show species abundance for the three transects and the three zones in the CM, and (c) and (d) show species richness by the three transects and the three zones.

in the Arabian Peninsula, Iraq, Syria, and Lebanon, covering an area of $3,000,000 \mathrm{~km}^{2}[22]$.

Our survey recorded 31 more bird species versus the most recent, rapid assessment which is potentially due to the nature of the previous surveys, which were rapid assessments of bird species undertaken across the entirety of the Mesopotamian marshlands (Hawiza Marsh to the east of the Tigris River, Hammar Marsh to the south of the Euphrates River, and the Central Marsh between the Tigris and Euphrates Rivers) [4]. By focusing on one of the marshes, we were able to conduct more intensive surveys, which detected more bird species. For this reason, there is a clear need to undertake further, intensive surveys in the other two Mesopotamian marshes to provide accurate, up-to-date information. Recent national water and biodiversity strategies have indicated that it is no longer appropriate to consider all three marshes as one conservation unit, as the connections between the water bodies have severely declined due to extreme water scarcity [10]. As such, there is an urgent need to develop management plans for each of the three Mesopotamian marshes.

The greatest bird species abundance in the CM was in winter (December, January, and February). The area of the 


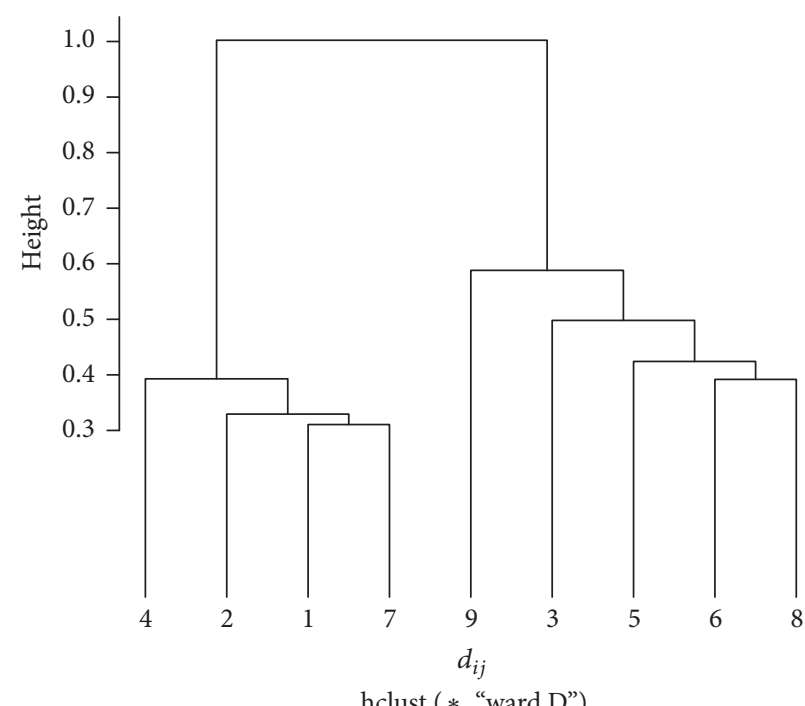

hclust (*, "ward.D")

(a)

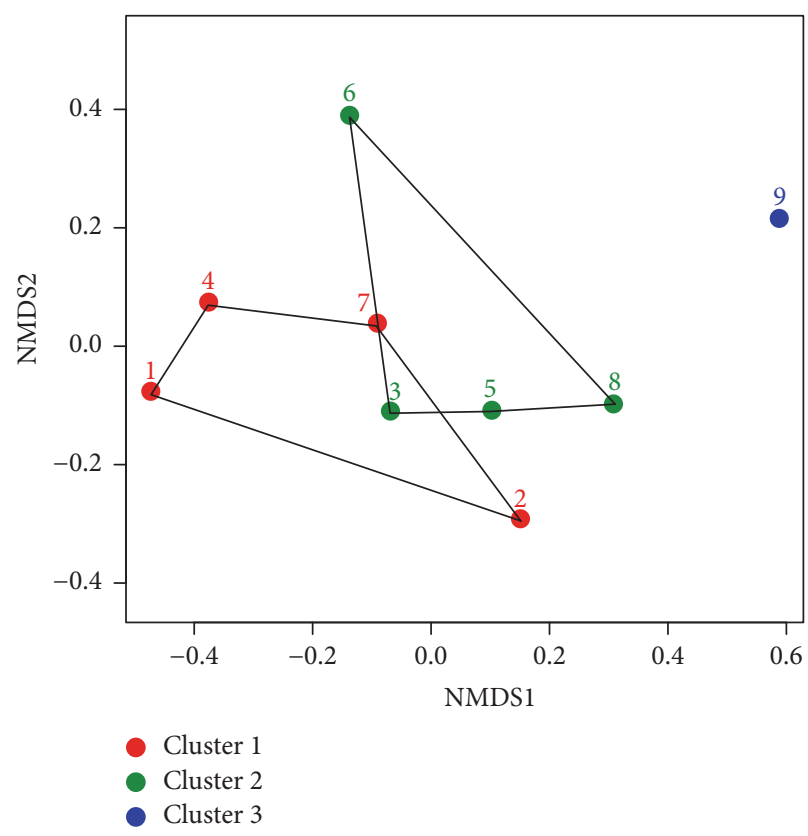

(b)

FIGURE 5: NMDS cluster analysis for birds in the CM. (a) shows a dendrogram based on a Bray-Curtis dissimilarity matrix. This dendrogram was then cut to give three groupings based on similarities in bird community composition as shown both by the dendrogram and by the NMDS ordination plot. (b) shows the results of the NMDS ordination, with each zone/transect complement (e.g., zone one transect one is site one and zone one transect two is site two) coloured according to grouping and surrounded by a convex hull. The ordination shows three different groupings of sites (note: the inclusion of site three within cluster one does not represent a failing with our method but a consequence of the way NMDS plots are visualized).

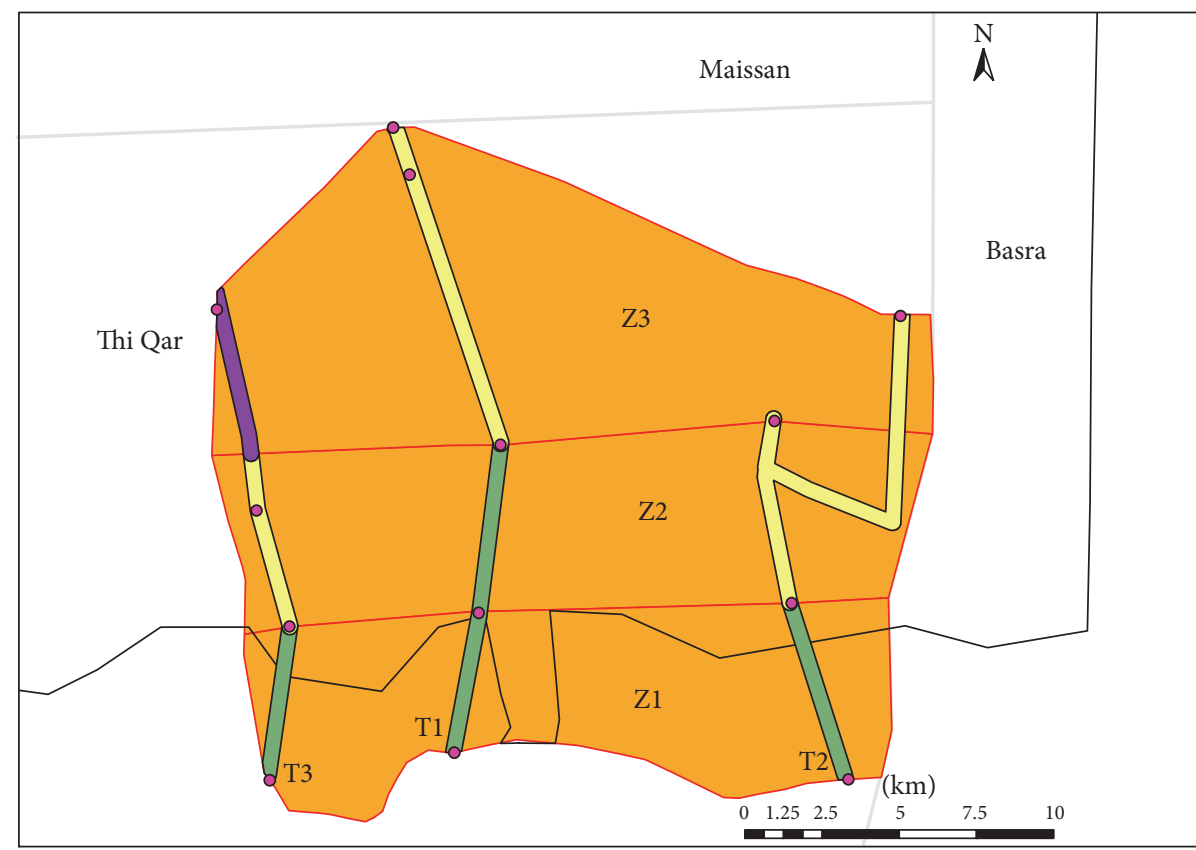

Stop points

National Park area

Study area zones

Governorate boundaries
NMDS clusters

Cluster 1

Cluster 2

Cluster 3

FIgURE 6: NMDS cluster analysis for birds in the CM, surveys from October 2013 to June 2014 showing the spatial locations of the three different bird communities identified by the NMDS analysis. 
TABLE 4: Species observations and counts (October, 2013-June, 2014) in the Iraqi Central Marsh. Scientific names are provided in Appendix Table 7.

\begin{tabular}{|c|c|c|c|c|c|c|c|c|c|c|}
\hline & \multirow{2}{*}{ Species English name } & \multicolumn{9}{|c|}{ Species observations \& counts (Oct, 2013-Jun, 2014) } \\
\hline & & Oct & Nov & Dec & Jan & Feb & Mar & Apr & May & Jun \\
\hline (1) & Black Francolin & 0 & 2 & 4 & 6 & 1 & 0 & 4 & 2 & 2 \\
\hline (2) & Greylag Goose & 7 & 0 & 77 & 10 & 0 & 0 & 0 & 0 & 0 \\
\hline (3) & Mallard & 0 & 0 & 47 & 55 & 0 & 2 & 0 & 0 & 0 \\
\hline (4) & Northern Shoveler & 0 & 0 & 46 & 0 & 0 & 0 & 0 & 0 & 0 \\
\hline (5) & Northern Pintail & 0 & 0 & 400 & 175 & 15 & 0 & 0 & 0 & 0 \\
\hline (6) & Garganey & 0 & 0 & 0 & 0 & 0 & 0 & 8 & 0 & 0 \\
\hline (7) & Eurasian Teal & 0 & 0 & 66 & 168 & 45 & 47 & 0 & 0 & 0 \\
\hline (8) & Marbled Duck & 0 & 0 & 35 & 5 & 10 & 0 & 22 & 0 & 0 \\
\hline (9) & Ferruginous Duck & 0 & 8 & 21 & 0 & 10 & 0 & 0 & 0 & 0 \\
\hline (10) & Little Grebe & 58 & 42 & 70 & 95 & 81 & 40 & 14 & 30 & 72 \\
\hline (11) & Great Crested Grebe & 0 & 0 & 0 & 5 & 0 & 0 & 0 & 0 & 0 \\
\hline (12) & White Stork & 0 & 0 & 380 & 200 & 40 & 0 & 0 & 0 & 0 \\
\hline (13) & African Sacred Ibis & 0 & 0 & 0 & 2 & 0 & 0 & 0 & 0 & 0 \\
\hline (14) & Glossy Ibis & 0 & 0 & 25 & 9 & 2 & 230 & 10 & 0 & 11 \\
\hline (15) & Eurasian Bittern & 0 & 1 & 0 & 2 & 2 & 2 & 2 & 0 & 1 \\
\hline$(16)$ & Little Bittern & 0 & 1 & 0 & 0 & 0 & 0 & 111 & 203 & 143 \\
\hline (17) & Black-Crowned Night Heron & 0 & 0 & 2 & 1 & 0 & 1 & 11 & 21 & 56 \\
\hline (18) & Squacco Heron & 41 & 132 & 181 & 85 & 116 & 970 & 100 & 39 & 90 \\
\hline (19) & Cattle Egret & 55 & 83 & 0 & 18 & 6 & 0 & 0 & 0 & 0 \\
\hline$(20)$ & Grey Heron & 3 & 13 & 1 & 0 & 51 & 23 & 11 & 0 & 0 \\
\hline$(21)$ & Purple Heron & 8 & 9 & 19 & 11 & 6 & 10 & 33 & 12 & 8 \\
\hline$(22)$ & Great White Egret & 0 & 0 & 0 & 0 & 10 & 12 & 0 & 0 & 0 \\
\hline (23) & Little Egret & 74 & 68 & 1046 & 750 & 665 & 380 & 33 & 12 & 505 \\
\hline (24) & Great White pelican & 0 & 0 & 533 & 500 & 150 & 0 & 0 & 0 & 0 \\
\hline (25) & Pygmy Cormorant & 0 & 0 & 0 & 0 & 0 & 0 & 7 & 21 & 23 \\
\hline$(26)$ & Great Cormorant & 2 & 1 & 0 & 5 & 0 & 0 & 0 & 0 & 0 \\
\hline$(27)$ & Black-Winged Kite & 0 & 0 & 0 & 1 & 0 & 0 & 0 & 0 & 0 \\
\hline$(28)$ & White-Tailed Sea Eagle & 0 & 0 & 1 & 0 & 0 & 0 & 0 & 0 & 0 \\
\hline (29) & Cinereous Vulture & 0 & 0 & 2 & 0 & 0 & 0 & 0 & 0 & 0 \\
\hline$(30)$ & Short-Toed Snake-Eagle & 0 & 0 & 0 & 0 & 2 & 0 & 0 & 0 & 0 \\
\hline$(31)$ & Western Marsh Harrier & 12 & 13 & 28 & 23 & 18 & 15 & 1 & 1 & 0 \\
\hline$(32)$ & Pallid Harrier & 0 & 1 & 0 & 1 & 0 & 1 & 0 & 0 & 0 \\
\hline$(33)$ & Montagu’s Harrier & 0 & 0 & 0 & 0 & 1 & 0 & 0 & 0 & 0 \\
\hline$(34)$ & Eurasian Sparrow hawk & 0 & 1 & 0 & 0 & 2 & 1 & 0 & 0 & 0 \\
\hline$(35)$ & Long-Legged Buzzard & 0 & 0 & 0 & 1 & 0 & 0 & 0 & 0 & 0 \\
\hline$(36)$ & Greater Spotted Eagle & 0 & 0 & 0 & 1 & 0 & 2 & 1 & 0 & 0 \\
\hline$(37)$ & Steppe Eagle & 1 & 1 & 0 & 0 & 0 & 2 & 0 & 0 & 0 \\
\hline$(38)$ & Common Kestrel & 0 & 0 & 1 & 0 & 0 & 0 & 0 & 0 & 0 \\
\hline$(39)$ & Eurasian Hobby & 0 & 1 & 0 & 0 & 0 & 0 & 0 & 0 & 0 \\
\hline$(40)$ & Water Rail & 1 & 0 & 0 & 0 & 0 & 0 & 0 & 0 & 0 \\
\hline (41) & Little Crake & 0 & 1 & 0 & 0 & 0 & 0 & 1 & 0 & 0 \\
\hline$(42)$ & Spotted Crake & 0 & 1 & 0 & 0 & 0 & 0 & 0 & 0 & 0 \\
\hline$(43)$ & Purple Swamphen & 0 & 8 & 0 & 3 & 0 & 7 & 18 & 0 & 2 \\
\hline$(44)$ & Common Moorhen & 15 & 17 & 10 & 22 & 13 & 2 & 3 & 2 & 11 \\
\hline$(45)$ & Common Coot & 0 & 4 & 87 & 245 & 125 & 14 & 0 & 0 & 0 \\
\hline$(46)$ & Black-Winged Stilt & 28 & 14 & 25 & 236 & 44 & 17 & 136 & 42 & 75 \\
\hline$(47)$ & Spur-Winged Lapwing & 1 & 0 & 0 & 0 & 0 & 2 & 19 & 9 & 7 \\
\hline$(48)$ & Red-Wattled Lapwing & 12 & 9 & 5 & 9 & 1 & 3 & 4 & 7 & 6 \\
\hline$(49)$ & White-Tailed Lapwing & 21 & 12 & 24 & 154 & 90 & 40 & 57 & 45 & 48 \\
\hline
\end{tabular}


TABle 4: Continued.

\begin{tabular}{|c|c|c|c|c|c|c|c|c|c|c|}
\hline & \multirow{2}{*}{ Species English name } & \multicolumn{9}{|c|}{ Species observations \& counts (Oct, 2013-Jun, 2014) } \\
\hline & & Oct & Nov & Dec & Jan & Feb & Mar & Apr & May & Jun \\
\hline$(50)$ & Common Ringed Plover & 9 & 6 & 4 & 10 & 3 & 0 & 0 & 0 & 0 \\
\hline$(51)$ & Little Ringed Plover & 0 & 2 & 0 & 0 & 0 & 0 & 3 & 2 & 0 \\
\hline$(52)$ & Kentish Plover & 4 & 10 & 43 & 23 & 13 & 0 & 0 & 0 & 2 \\
\hline (53) & Common Snipe & 1 & 0 & 0 & 1 & 0 & 2 & 21 & 0 & 0 \\
\hline$(54)$ & Common Redshank & 0 & 0 & 0 & 0 & 1 & 11 & 8 & 0 & 0 \\
\hline$(55)$ & Marsh Sandpiper & 0 & 6 & 0 & 19 & 8 & 28 & 0 & 0 & 0 \\
\hline$(56)$ & Common Greenshank & 1 & 0 & 0 & 0 & 0 & 0 & 2 & 0 & 0 \\
\hline (57) & Green Sandpiper & 3 & 1 & 0 & 1 & 4 & 2 & 0 & 0 & 0 \\
\hline$(58)$ & Wood Sandpiper & 0 & 0 & 0 & 0 & 1 & 0 & 0 & 0 & 0 \\
\hline (59) & Terek Sandpiper & 3 & 0 & 0 & 0 & 1 & 0 & 0 & 0 & 0 \\
\hline$(60)$ & Common Sandpiper & 3 & 6 & 8 & 4 & 5 & 4 & 8 & 7 & 0 \\
\hline$(61)$ & Sanderling & 0 & 0 & 0 & 1 & 0 & 0 & 0 & 0 & 0 \\
\hline$(62)$ & Little Stint & 0 & 1 & 0 & 5 & 1 & 0 & 6 & 3 & 0 \\
\hline$(63)$ & Curlew Sandpiper & 0 & 0 & 0 & 0 & 0 & 0 & 5 & 2 & 0 \\
\hline (64) & Ruff & 0 & 0 & 0 & 0 & 0 & 1 & 85 & 6 & 0 \\
\hline$(65)$ & Collared Pratincole & 0 & 0 & 0 & 0 & 0 & 0 & 15 & 9 & 4 \\
\hline (66) & Slender-Billed Gull & 17 & 165 & 480 & 487 & 891 & 163 & 164 & 78 & 90 \\
\hline (67) & Black-Headed Gull & 0 & 35 & 130 & 246 & 685 & 232 & 149 & 17 & 0 \\
\hline (68) & Armenian Gull & 0 & 2 & 2 & 5 & 6 & 21 & 5 & 0 & 0 \\
\hline (69) & Gull-Billed Tern & 2 & 10 & 0 & 0 & 0 & 0 & 0 & 9 & 0 \\
\hline$(70)$ & Little Tern & 11 & 3 & 0 & 0 & 0 & 0 & 20 & 9 & 16 \\
\hline$(71)$ & Common Tern & 0 & 6 & 0 & 0 & 0 & 53 & 43 & 9 & 18 \\
\hline$(72)$ & Whiskered Tern & 53 & 81 & 639 & 741 & 279 & 113 & 61 & 125 & 63 \\
\hline (73) & White-Winged Tern & 0 & 0 & 0 & 0 & 0 & 0 & 0 & 21 & 0 \\
\hline$(74)$ & Pin-Tailed Sandgrouse & 0 & 0 & 0 & 0 & 0 & 23 & 16 & 0 & 0 \\
\hline$(75)$ & European Turtle Dove & 0 & 0 & 0 & 0 & 0 & 0 & 0 & 5 & 0 \\
\hline$(76)$ & Eurasian Collared Dove & 16 & 21 & 36 & 26 & 35 & 23 & 17 & 14 & 6 \\
\hline$(77)$ & Laughing Dove & 0 & 1 & 2 & 13 & 3 & 5 & 7 & 2 & 0 \\
\hline$(78)$ & Common Barn-Owl & 0 & 0 & 0 & 1 & 0 & 0 & 0 & 0 & 0 \\
\hline$(79)$ & Egyptian Nightjar & 0 & 0 & 0 & 0 & 0 & 0 & 0 & 1 & 0 \\
\hline$(80)$ & White-Breasted Kingfisher & 9 & 17 & 25 & 38 & 30 & 25 & 10 & 4 & 7 \\
\hline$(81)$ & Common Kingfisher & 10 & 12 & 29 & 18 & 25 & 17 & 5 & 1 & 3 \\
\hline$(82)$ & Pied Kingfisher & 236 & 318 & 542 & 500 & 461 & 293 & 269 & 245 & 147 \\
\hline$(83)$ & Blue-Cheeked Bee-Eater & 10 & 9 & 0 & 0 & 0 & 0 & 28 & 0 & 0 \\
\hline$(84)$ & European Bee-Eater & 0 & 0 & 0 & 0 & 0 & 0 & 8 & 0 & 0 \\
\hline$(85)$ & Eurasian Hoopoe & 0 & 0 & 0 & 0 & 0 & 1 & 0 & 0 & 0 \\
\hline$(86)$ & Red-Backed Shrike & 3 & 0 & 0 & 0 & 0 & 0 & 0 & 52 & 0 \\
\hline (87) & Isabelline Shrike & 6 & 8 & 12 & 25 & 5 & 2 & 0 & 0 & 0 \\
\hline$(88)$ & Turkestan Isabelline Shrike & 2 & 0 & 0 & 1 & 2 & 0 & 1 & 0 & 0 \\
\hline (89) & Lesser Grey Shrike & 0 & 0 & 0 & 0 & 0 & 0 & 0 & 31 & 0 \\
\hline$(90)$ & Eurasian Golden Oriole & 0 & 0 & 0 & 0 & 0 & 0 & 0 & 1 & 0 \\
\hline$(91)$ & Hooded Crow & 0 & 0 & 2 & 0 & 5 & 2 & 0 & 0 & 0 \\
\hline$(92)$ & Mesopotamian Crow & 0 & 0 & 2 & 0 & 0 & 1 & 0 & 0 & 0 \\
\hline (93) & Crested Lark & 32 & 3 & 10 & 4 & 6 & 4 & 9 & 19 & 24 \\
\hline (94) & White-Eared Bulbul & 0 & 1 & 1 & 2 & 4 & 0 & 0 & 0 & 0 \\
\hline (95) & Sand Martin & 0 & 2 & 0 & 0 & 0 & 27 & 54 & 5 & 2 \\
\hline (96) & Barn Swallow & 5 & 0 & 0 & 0 & 11 & 29 & 38 & 35 & 12 \\
\hline (97) & Willow Warbler & 0 & 0 & 0 & 0 & 0 & 0 & 1 & 0 & 0 \\
\hline$(98)$ & Common Chiffchaff & 7 & 20 & 38 & 48 & 34 & 8 & 18 & 0 & 0 \\
\hline
\end{tabular}


TABLE 4: Continued.

\begin{tabular}{|c|c|c|c|c|c|c|c|c|c|c|}
\hline \multirow{2}{*}{\multicolumn{2}{|c|}{ Species English name }} & \multicolumn{9}{|c|}{ Species observations \& counts (Oct, 2013-Jun, 2014) } \\
\hline & & Oct & Nov & Dec & Jan & Feb & Mar & Apr & May & Jun \\
\hline$(99)$ & Basra Reed Warbler & 0 & 0 & 0 & 0 & 0 & 0 & 14 & 42 & 66 \\
\hline$(100)$ & Great Reed Warbler & 1 & 2 & 0 & 0 & 0 & 0 & 38 & 57 & 42 \\
\hline$(101)$ & Sedge Warbler & 0 & 2 & 0 & 0 & 0 & 0 & 1 & 2 & 0 \\
\hline$(102)$ & Eurasian Reed-Warbler & 0 & 0 & 0 & 0 & 1 & 0 & 0 & 2 & 0 \\
\hline$(103)$ & Graceful Prinia & 13 & 9 & 11 & 23 & 73 & 41 & 78 & 104 & 61 \\
\hline$(104)$ & Iraq Babbler & 5 & 7 & 11 & 25 & 27 & 9 & 58 & 17 & 11 \\
\hline$(105)$ & Afghan (Common) Babbler & 0 & 0 & 0 & 16 & 6 & 18 & 0 & 4 & 0 \\
\hline$(106)$ & Common Starling & 0 & 42 & 105 & 252 & 549 & 47 & 2 & 1 & 0 \\
\hline$(107)$ & Song Thrush & 0 & 0 & 0 & 1 & 0 & 0 & 0 & 0 & 0 \\
\hline$(108)$ & European Robin & 0 & 2 & 5 & 1 & 0 & 0 & 0 & 0 & 0 \\
\hline$(109)$ & Bluethroat & 0 & 1 & 1 & 1 & 1 & 0 & 0 & 0 & 0 \\
\hline$(110)$ & Rufous-Tailed Scrub-Robin & 0 & 1 & 0 & 0 & 0 & 0 & 0 & 0 & 0 \\
\hline (111) & Common Redstart & 0 & 0 & 0 & 0 & 0 & 0 & 1 & 0 & 0 \\
\hline$(112)$ & Whinchat & 0 & 5 & 0 & 0 & 0 & 0 & 0 & 4 & 0 \\
\hline$(113)$ & Common Stonechat & 0 & 0 & 3 & 3 & 0 & 0 & 0 & 0 & 0 \\
\hline$(114)$ & Northern Wheatear & 0 & 0 & 0 & 0 & 0 & 6 & 8 & 0 & 0 \\
\hline$(115)$ & Black-Eared Wheatear & 0 & 0 & 0 & 0 & 0 & 0 & 1 & 0 & 0 \\
\hline$(116)$ & House Sparrow & 221 & 142 & 158 & 102 & 158 & 75 & 140 & 70 & 58 \\
\hline$(117)$ & Spanish Sparrow & 0 & 0 & 0 & 0 & 0 & 6 & 8 & 0 & 0 \\
\hline (118) & Dead Sea Sparrow & 50 & 450 & 54 & 0 & 30 & 10 & 15 & 4 & 0 \\
\hline (119) & Yellow Wagtail & 0 & 2 & 0 & 0 & 0 & 43 & 86 & 1 & 0 \\
\hline$(120)$ & Citrine Wagtail & 1 & 0 & 0 & 1 & 1 & 4 & 4 & 0 & 0 \\
\hline$(121)$ & White Wagtail & 51 & 25 & 134 & 80 & 61 & 74 & 9 & 0 & 0 \\
\hline$(122)$ & Water Pipit & 5 & 26 & 22 & 20 & 16 & 2 & 1 & 0 & 0 \\
\hline (123) & Corn Bunting & 0 & 0 & 0 & 1 & 0 & 0 & 0 & 0 & 0 \\
\hline$(124)$ & Ortolan Bunting & 0 & 0 & 0 & 0 & 0 & 0 & 1 & 0 & 0 \\
\hline$(125)$ & Reed Bunting & 0 & 0 & 0 & 0 & 1 & 0 & 0 & 0 & 0 \\
\hline
\end{tabular}

TABLE 5: Field notes and breeding evidence of birds from Oct, 2013, to Jun, 2014, in the Iraqi Central Marsh.

Survey Important notes

(i) Wide distribution of Pied Kingfisher, Cattle Egret (especially on the back of the water buffalos), Crested Lark, House Sparrow

Oct, 2013 (ii) Recording Greylag Goose as first arrival in this month to the CM
(iii) Recording Red-Backed Shrike (we just recorded this species in Oct and May)

(iv) Recording Water Rail just in this month

(i) Wide distribution of Pied Kingfisher, Cattle Egret (especially on the back of the water buffalos), Crested Lark, House Sparrow

(ii) Recording Starling, Coot, Yellow Wagtail, Robin, Arminian Gull, Ferruginous Duck, Bluethroat as first arrival in this month

Nov, 2013 to the CM

(iii) Large number of Dead Sea Sparrow, Winchat comparing with the observations of same species in the 9 surveys

(iv) Recording Little and Spotted Crake

(i) Reduction of Cattle Egret observations

(ii) Dominance of Little Egret

(iii) Appearance/presence of Eagles and Vultures in the area of study (e.g., White-Tailed Eagle and Black Vulture)

(iv) First arrivals of huge number of water birds and ducks to the area of study (e.g., Teal, Northern Pintail, Mallard, Shoveler).

Dec, 2013 (v) Increasing of Common Kingfisher, White-Breasted Kingfisher, White Wagtail, Marsh Harrier, Kentish Plover, Starling,

Slender Bill and Black-Headed Gulls, Coot, Chiffchaff

(vi) First arrival of White Stork and Pelican White

(vii) First observation of Spanish Sparrow, Marbled Teal, Common Kestrel, Glossy Ibis of the 9 surveys

(viii) Increasing of birds hunting 
TABLE 5: Continued.

\begin{tabular}{ll}
\hline Survey & Important notes \\
& (i) Dominance of Whiskered Tern and Little Egret \\
(ii) Wide distribution of Black-Winged Stilt
\end{tabular}

(i) Dominant and wide distribution of Squacco Heron in all transects and zones

(ii) Decrease in the numbers of Little Egret

(iii) Decrease of hunting

Mar, 2014 (iv) Decrease in numbers of Starling, Water Pipit, Coot, ducks

(v) Disappearing of Kentish Plover, Common Ringed Plover, Cattle Egret, White Stork, Pelican White, White-Cheeked Bulbul, Bluthroat

(vi) Highest observations/numbers of Marsh Sand Piper, Yellow Wagtail, Common Tern, Glossy Ibis, Common Red Shank

(vii) First observation of Spur-Winged Lapwing, San Marten, Pin-Tailed Sandgrouse, Northern Wheatear, Hoopoe, Ruff

(i) Start of nesting of Iraq Babbler and House Sparrow

(ii) Arrival of Warblers (Great Reed Warbler being higher in numbers than Basra Reed Warbler)

(iii) Disappearing of Marsh Harrier

(iv) Dominance of Little Bittern and Great Reed Warbler

(v) Marbled Duck can be seen easily compared to other months

(vi) Decrease in numbers of Squacco Heron, Common Kingfisher, White-Breasted Kingfisher, Starling, Glossy Ibis, Little Egret

(vii) Increasing numbers of Glassful Prinia, Purple Swamphen, Northern Wheatear, Ruff, Spur-Winged Lapwing, Purple Heron compared to other months

(viii) Night Heron can be seen easily

(ix) Observation of Blue-Cheeked Beater just in this month

Apr, 2014 (x) Disappearing of Great White Egret, Common Babbler, Coot, Teal, Marsh Sandpiper

(xi) First observation of Pygmy Cormorant, Willow Warbler, Collared Pratincole, European Bee-Eater, Garganey, Curlew Sandpiper

(xii) Recording Greater-Spotted Eagle

(xiii) Breeding evidences

(a) Nest with chicks of Red-Wattled Lapwing (GPS coordinates 0706280, 3436379)

(b) Empty nest of Purple Swamphen

(c) Nests of Graceful Prinia

(d) Empty nest of Warbler in transect 2

(e) Nest of House Sparrow

(f) Nest of Iraq Babbler

(i) Increase in numbers of Graceful Prinia, Basra Reed Warbler, Pygmy Cormorant

(ii) Decrease in numbers of Gulls and Whiskered Tern

(iii) Arrival of Red-Backed Shrike

(iv) Recording Winchat, Golden Oriole, White-Winged Black Tern, European Reed Warbler

(v) First observation of Lesser Grey Shrike, European Nightjar, Turtle Dove

(vi) Disappearing of Grey Heron, Chiffchaff, Citrine Wagtail, Red Shank, Northern Wheatear, White Wagtail

(vii) Breeding evidences

(a) Empty 2 nests of Warbles in transect 1, zone 3 (coordinates: 0683694, 3441836)

May, 2014 (b) Two nests (with 2 chicks and one egg in each nest) of Basra Reed Warbler in Transect 2, zone 3 (coordinates: 0706003 , 3441503 and 0705922,3441499 )

(c) Nest (with 2 eggs) of Collared Dove in transect 2, zone 1

(d) Chicks and huge numbers (2 colonies; each colony has more than 50 nest) of Whickered Tern nests in transect 2, zone 3 (each nest is floating on the water with 3 eggs) coordinates: 0705878, 344280 and 0706394, 3437954

(e) Nest of Little Bittern with 4 eggs in transect 2 (coordinates: 0702287, 3430598)

(f) Two nests of White-Tailed Lapwing (one nest with 4 eggs and the second with 2 eggs), coordinates: 0684287, 3434033

(g) Nest of Graceful Prinia in transect 3

(h) Nest and chicks of House Sparrow in transect 3 
TABLE 5: Continued.

\begin{tabular}{l}
\hline Survey $\quad$ Important notes \\
(i) Increasing in numbers of Night Heron and Pygmy Cormorant (especially in transect 3), Little Grebe, Moorhen, Crested Lark \\
(ii) Assemblage of Little Egret in one huge group in transect 3 \\
(iii) Disappearing of Marsh Harrier, Starling, Black-Headed Gull, Red-Backed Shrike, Yellow Wagtail, Arminian Gull, \\
European Reed Warbler, Ruff, Lesser Grey Shrike \\
(iv) Breeding evidences \\
(a) Three nests of Basra Reed Warbler with 2 chicks and one egg in transect 1, zone 2 (coordinates: 0693162, 3436719 and \\
0684284, 3434030) \\
(b) Three nests of Basra Reed Warbler in transect 2, zone 3 (coordinates: 0705880, 3441550 and 0705874, 3441525) \\
(c) Nest with 4 eggs and chick of Little Bittern in transect 2, zone 1 (coordinates: 0693170, 3436726) \\
(d) Nest with 4 eggs of White-Tailed Lapwing in transect 2, zone 1 \\
(e) Nest with 2 eggs of Collared Dove in transect 2, zone 1 \\
(f) Chicks of Whiskered Tern in transect 2, zone 3 \\
(g) Chick and eggs of Pied Kingfisher \\
(h) Observation, juveniles of Little Grebe subspecies Tachybaptus ruficollis iraquensis in transect 2, zone 3
\end{tabular}

TABle 6: List of survey dates in the Central Marsh.

\begin{tabular}{lccccccccc}
\hline \multirow{2}{*}{ Month } & Oct, & Nov, & Dec, & Jan, & Feb, & Mar, & $\begin{array}{c}\text { Apr, } \\
2014\end{array}$ & $\begin{array}{c}\text { May, } \\
2014\end{array}$ & $\begin{array}{c}\text { Jun, } \\
2014\end{array}$ \\
\hline \multirow{3}{*}{ Day of the survey } & 2013 & 2013 & 2013 & 2014 & 2014 & 2014 & 16 & 17 & 9 \\
& 28 & 9 & 16 & 17 & 17 & 19 & 17 & 18 & 10 \\
& 29 & 10 & 17 & 19 & 18 & 20 & 18 & 19 \\
\hline
\end{tabular}

$\mathrm{CM}$ with the greatest abundance of birds was along transect two and in zone two. The highest species richness was in January and April along transect one and in zone two. However, there is potential of seasonal and observer bias. In winter, larger birds often form flocks in open areas and are therefore easy to detect. In summer many breeding birds may be less easy to detect (i.e., hidden from view in the reeds). Similarly in spring and autumn there will be huge numbers of migrant passerines using the marshes as a "stop-over" site to rest and feed. Our analysis is useful for comparing abundance and richness between areas within the same season but is perhaps less useful for comparing between seasons.

There has been recent interest in the potential population size of one of the most threatened species we recorded, the globally endangered Basra Reed Warbler, with major discrepancies of opinion regarding breeding population size (e.g., between $[18,19]$ and $[23])$. We recorded 11 nests in our study area (10 of them were independent nests; one in April, four in May, and five in June 2014). All recorded nests of Basra Reed Warbler in our surveys were built on reed stems only. Basra Reed Warbler shares its preferred reed bed habitat with the similar Great Reed Warbler. Our survey highlighted the dominance of Great Reed Warbler in April (the number of individuals recorded of Basra Reed Warbler in the area of study was 14, 42, and 66 and for Great Reed Warbler 38, 57, and 42 in April, May, and June 2014, resp.). It is unsafe to extrapolate from the numbers of nesting Basra Reed Warblers that we detected in our survey to the whole site, but clearly the Iraqi Marshlands holds a substantial population of this globally endangered species.

Although the CM is the first national park to be designated in Iraq [11] there is still a lack of detailed information on bird distribution across the site or in current management plans [4]. The CM area was considered as a Key Biodiversity Area (KBA) and an Important Birds Areas site and was divided into two main areas: core and buffer zones $[4,7,13]$. Our study provides more detailed information about bird abundance, richness, and assemblages. Three bird clusters were suggested for the first time in the area with zone two identified as containing large numbers of breeding birds. In contrast zone one had fewer species and a lower overall abundance; due to the proximity of human settlements zone one is also likely to receive more human disturbance (fishing, reed cutting, and buffalo grazing) than the other zones. More analysis is needed for the data to highlight differences between the 3 clusters.

Water levels in the Euphrates River, the main source of the CM's water, varied between autumn, winter, and summer $(1.29 \mathrm{~m}, 1.79 \mathrm{~m}$, and $1.66 \mathrm{~m}$ in October 2013 and January and June 2014, resp.; see Table 3), which is the main source of control of water levels and water quality inside the CM [11]. Rising water levels in the winter expand the flooded area away from Chibayish City and provide more suitable habitats for water birds in zone three. In addition, rising water levels in the Euphrates enable easier access for local people in zone one. Thus, keeping the minimum water level at $1.29 \mathrm{~m}$ in summer and winter could help and support wildlife in the $\mathrm{CM}$, especially in zone two and zone three.

Our results clearly show that the CM provides habitat for many bird species and that more intensive survey methods are needed for other two marshes found within the Mesopotamian marshland complex. Owing to national water scarcity, there is a real danger that the Mesopotamian marshlands will shrink in size, reducing the effective area of suitable habitat for many wetland species. We provide detailed information on the bird species found within the 


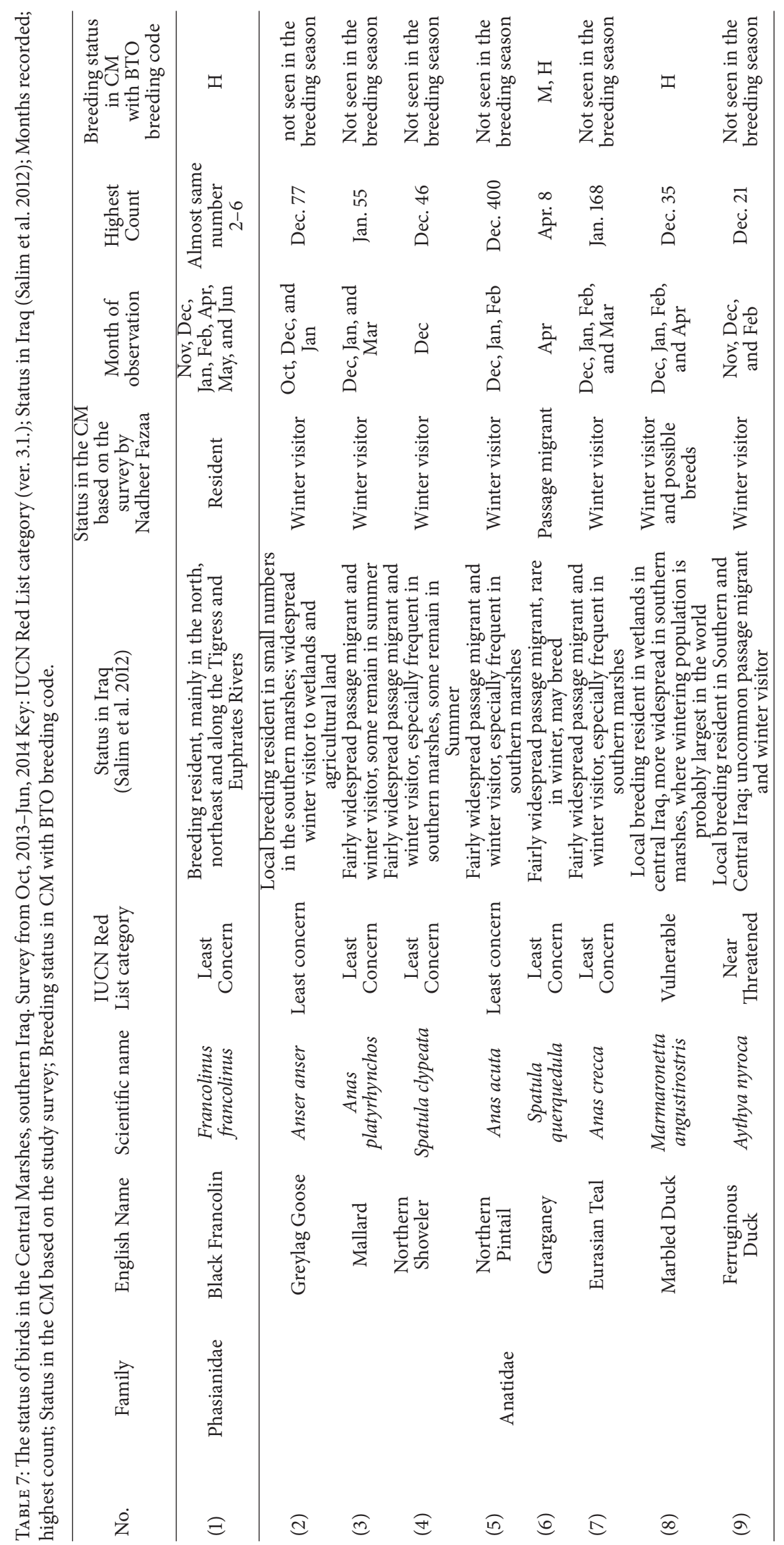




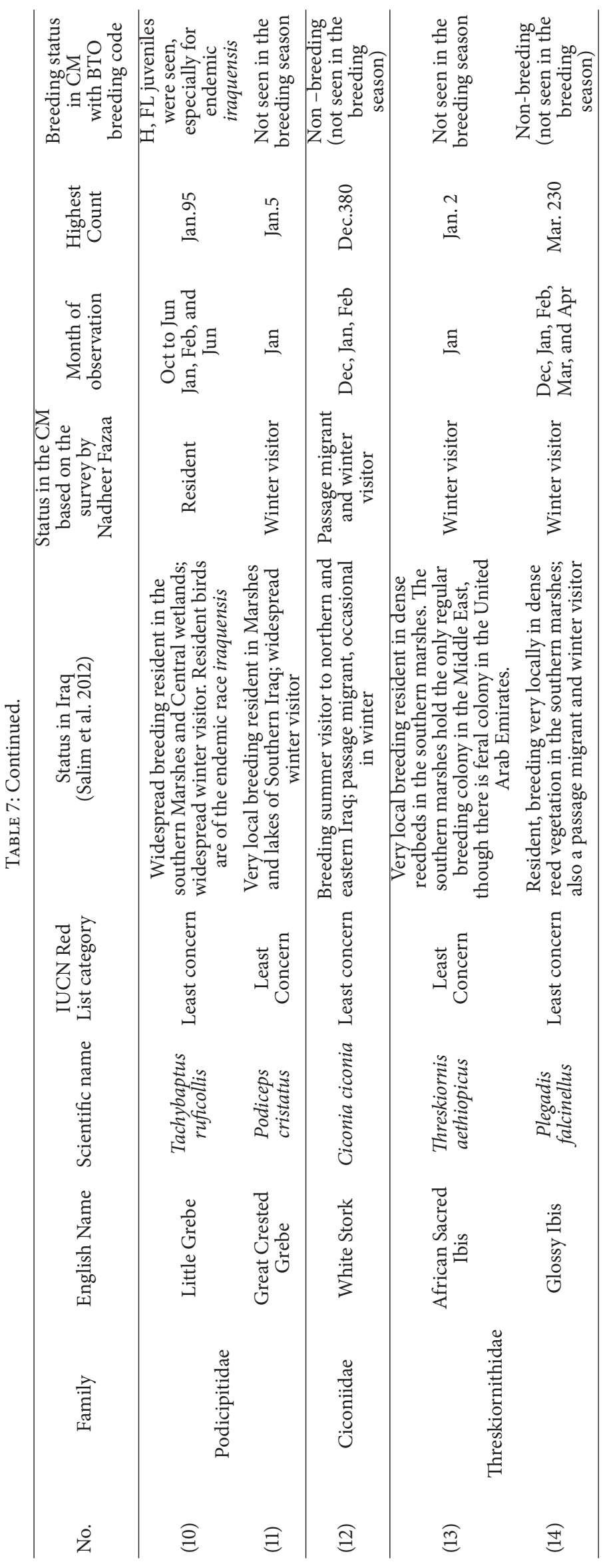




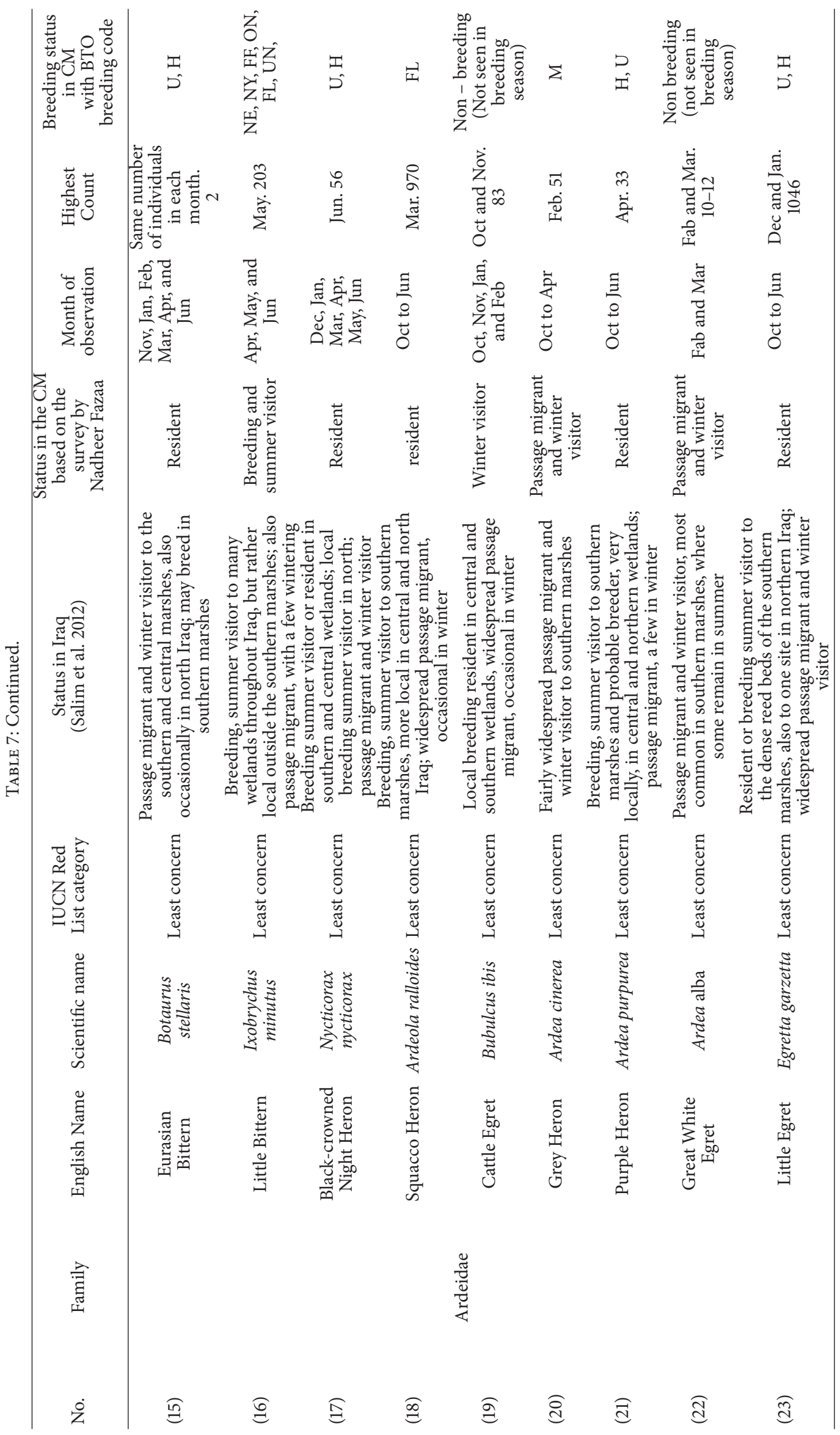




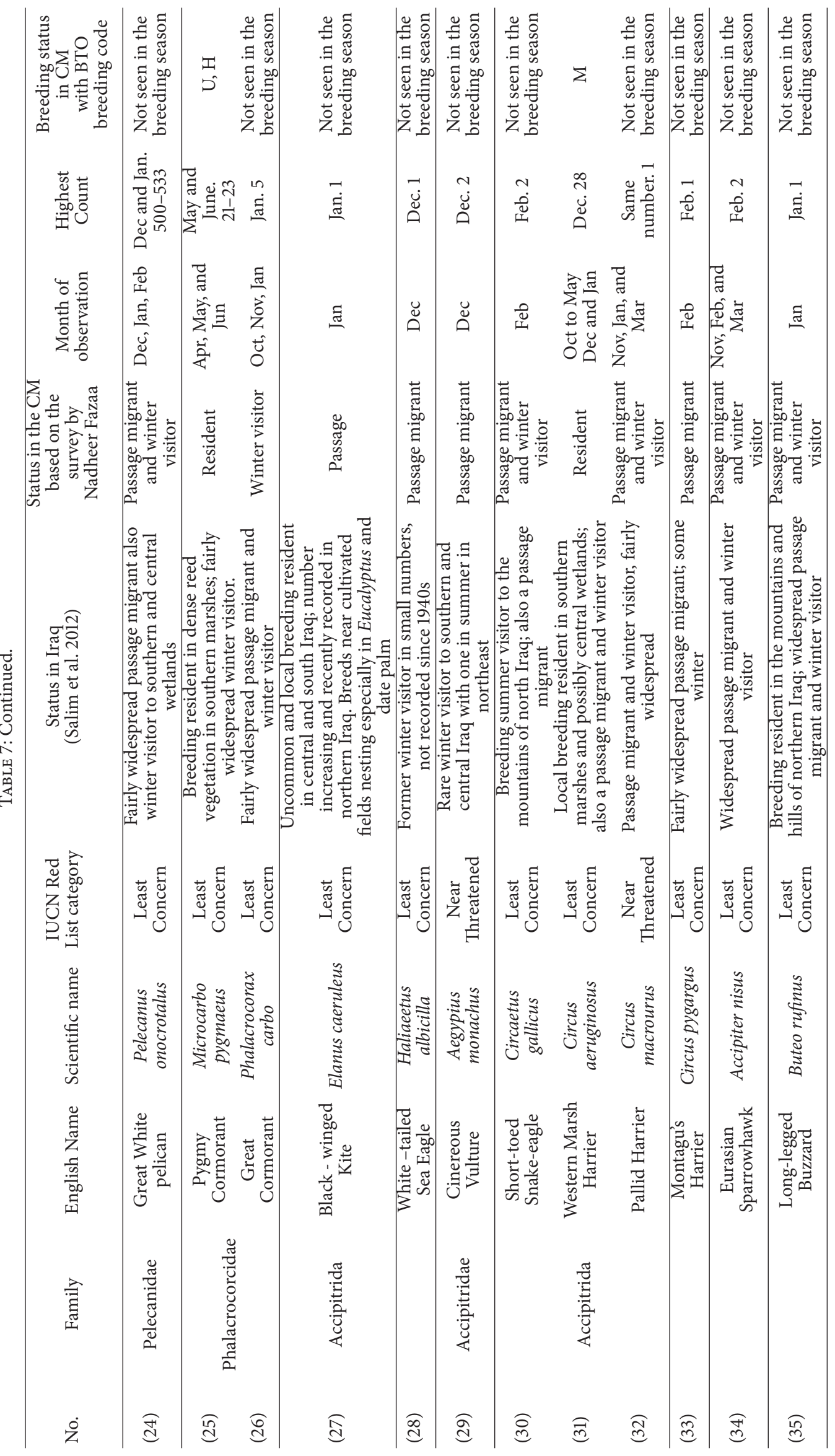




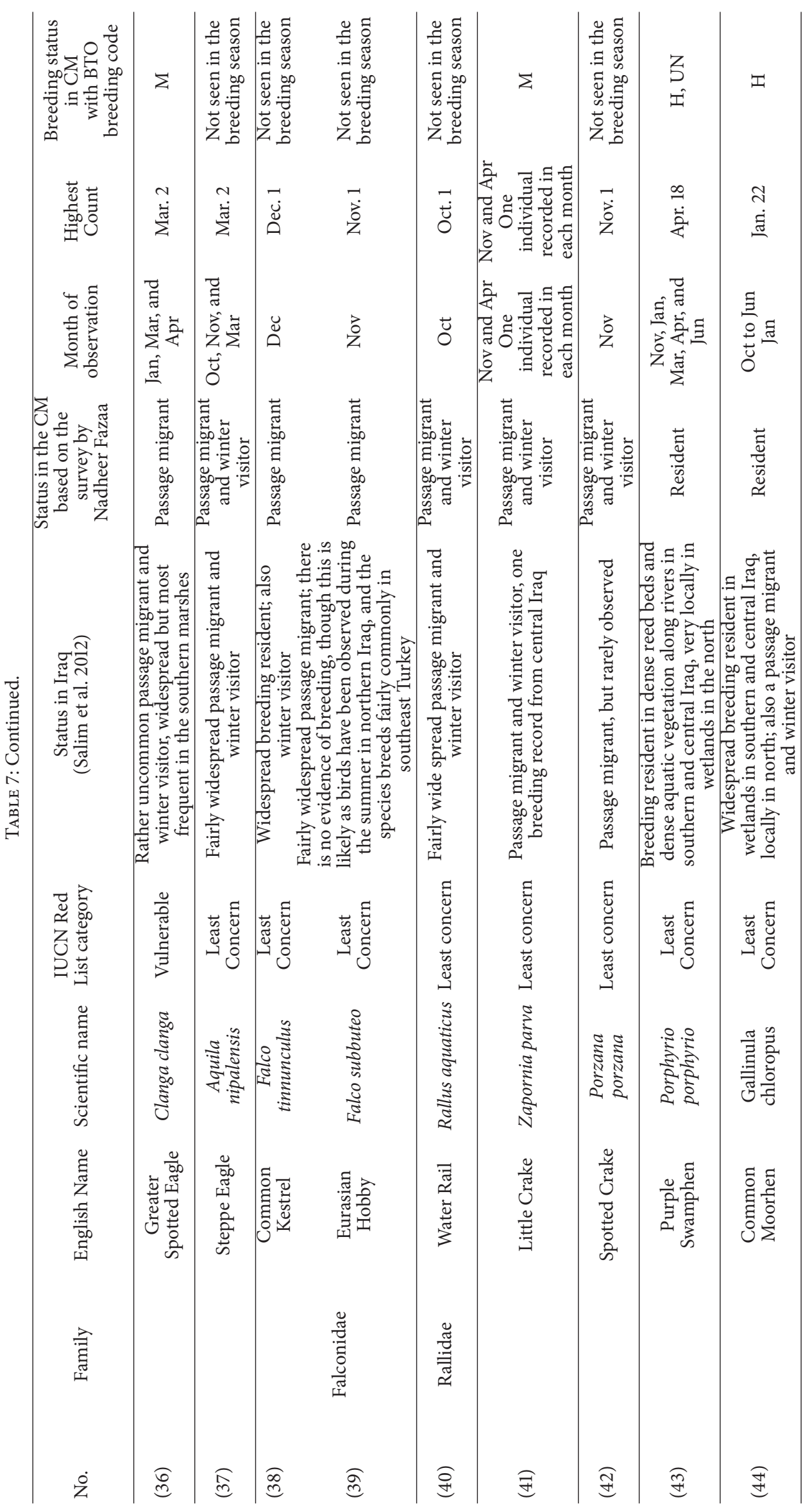




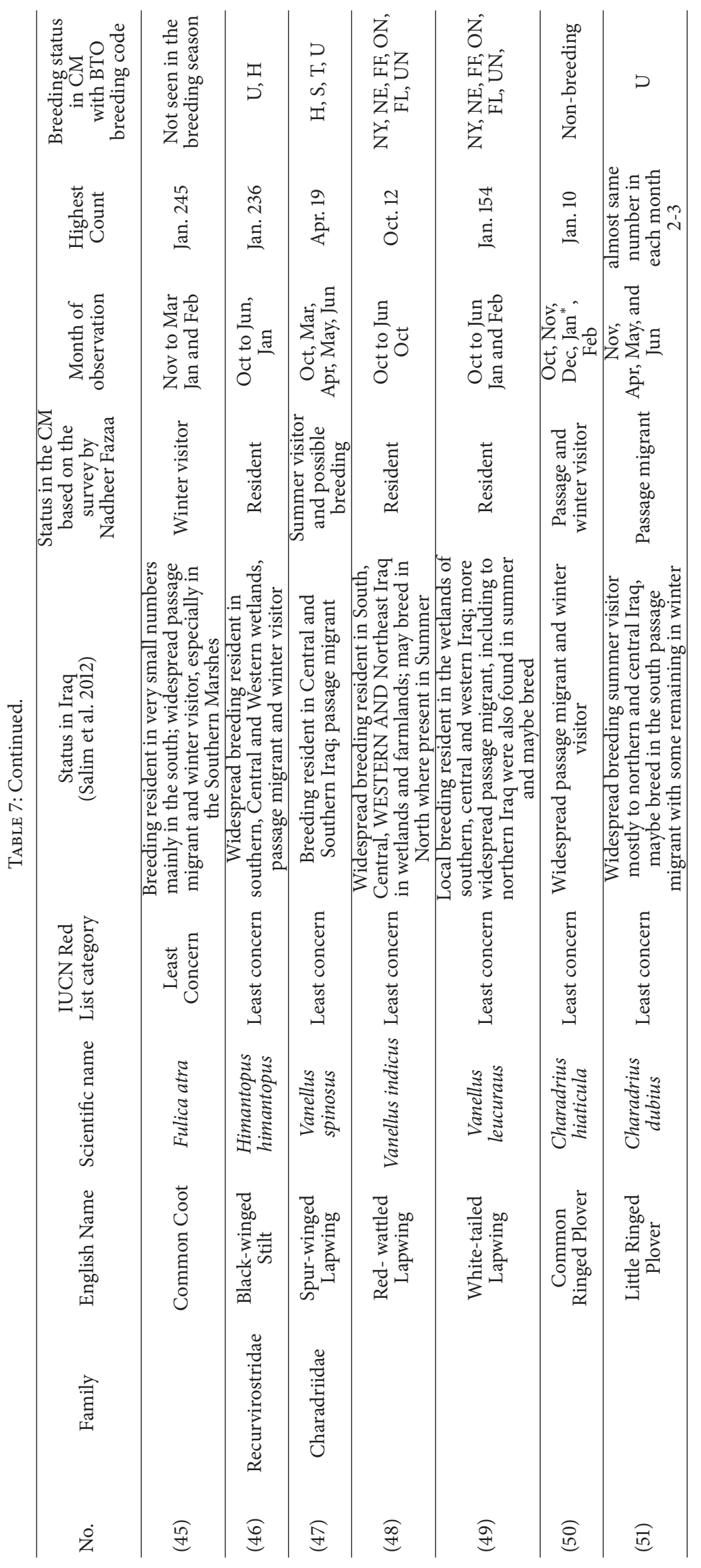




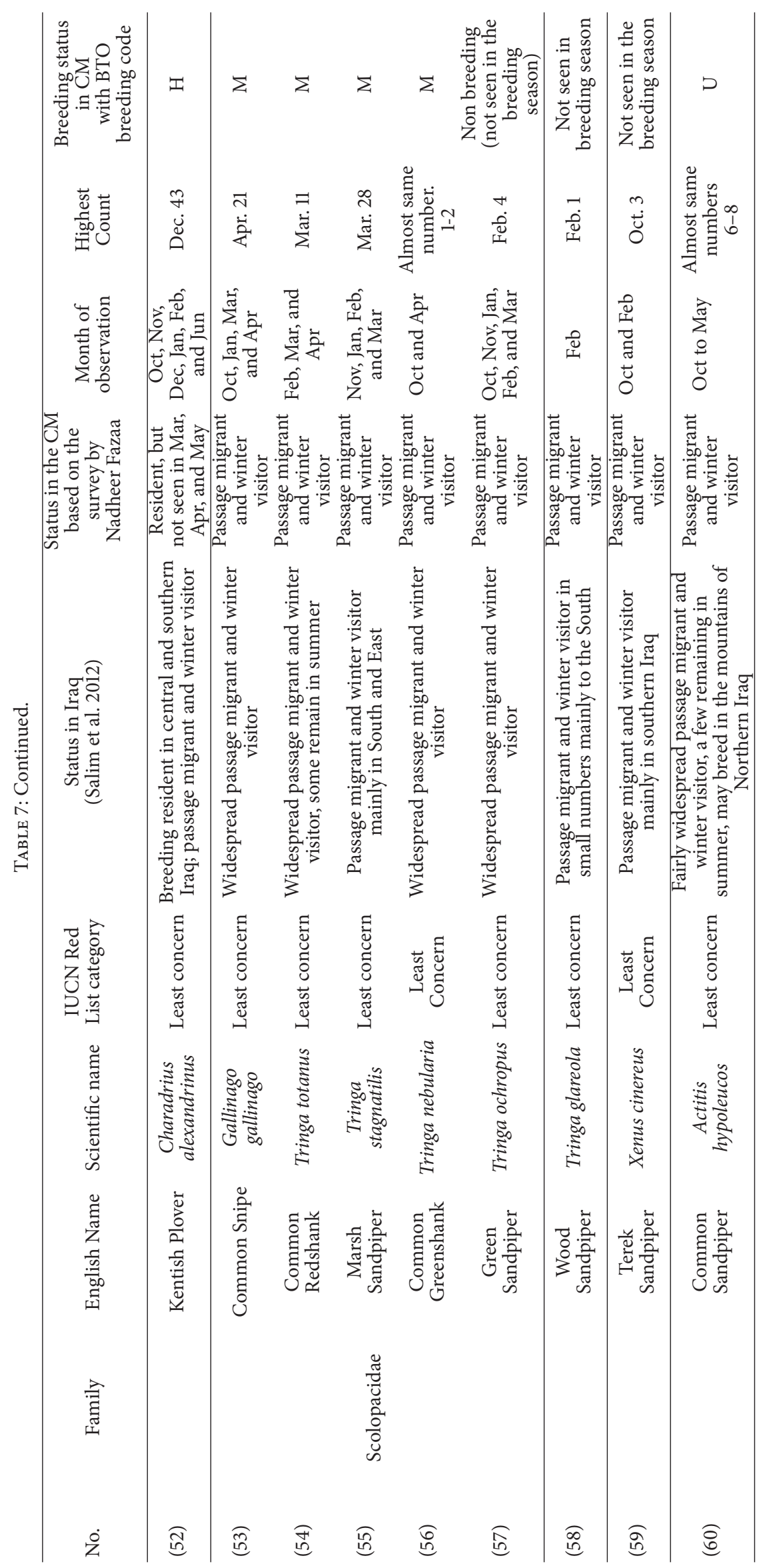




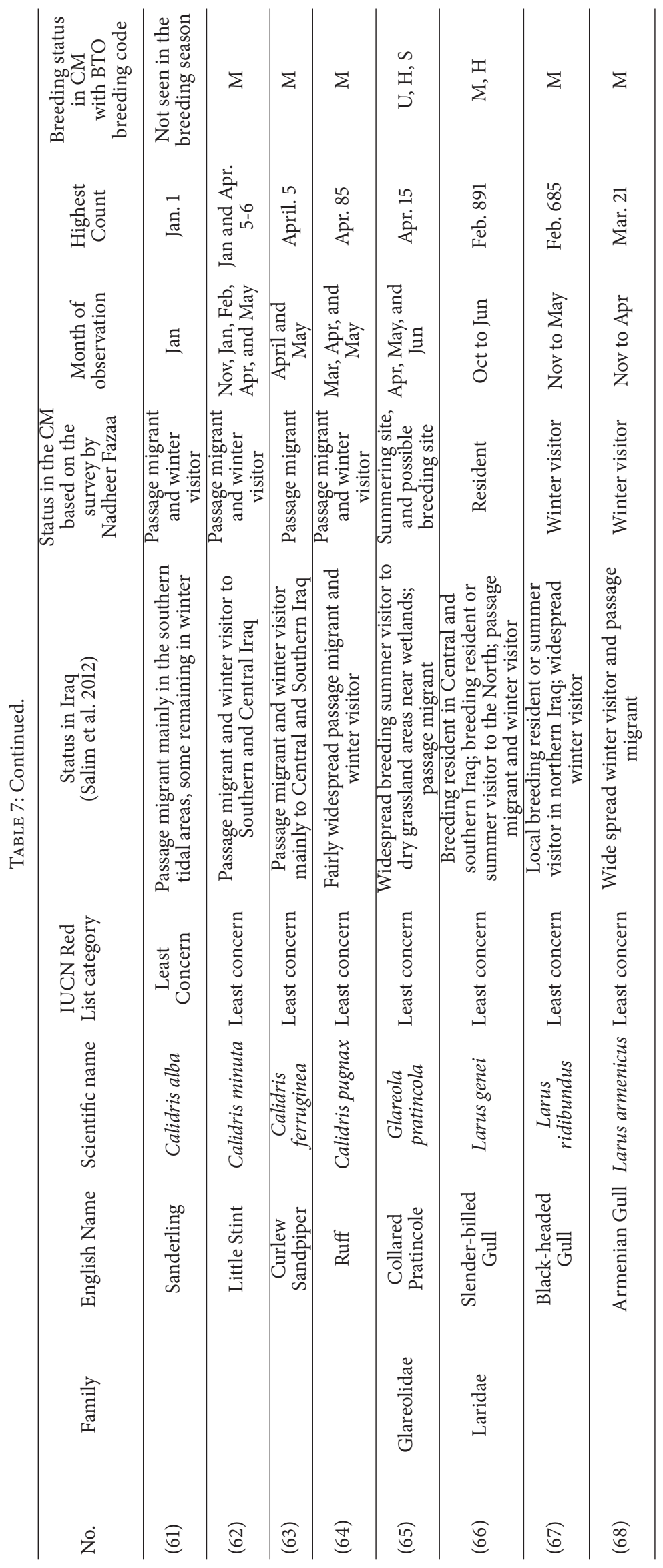




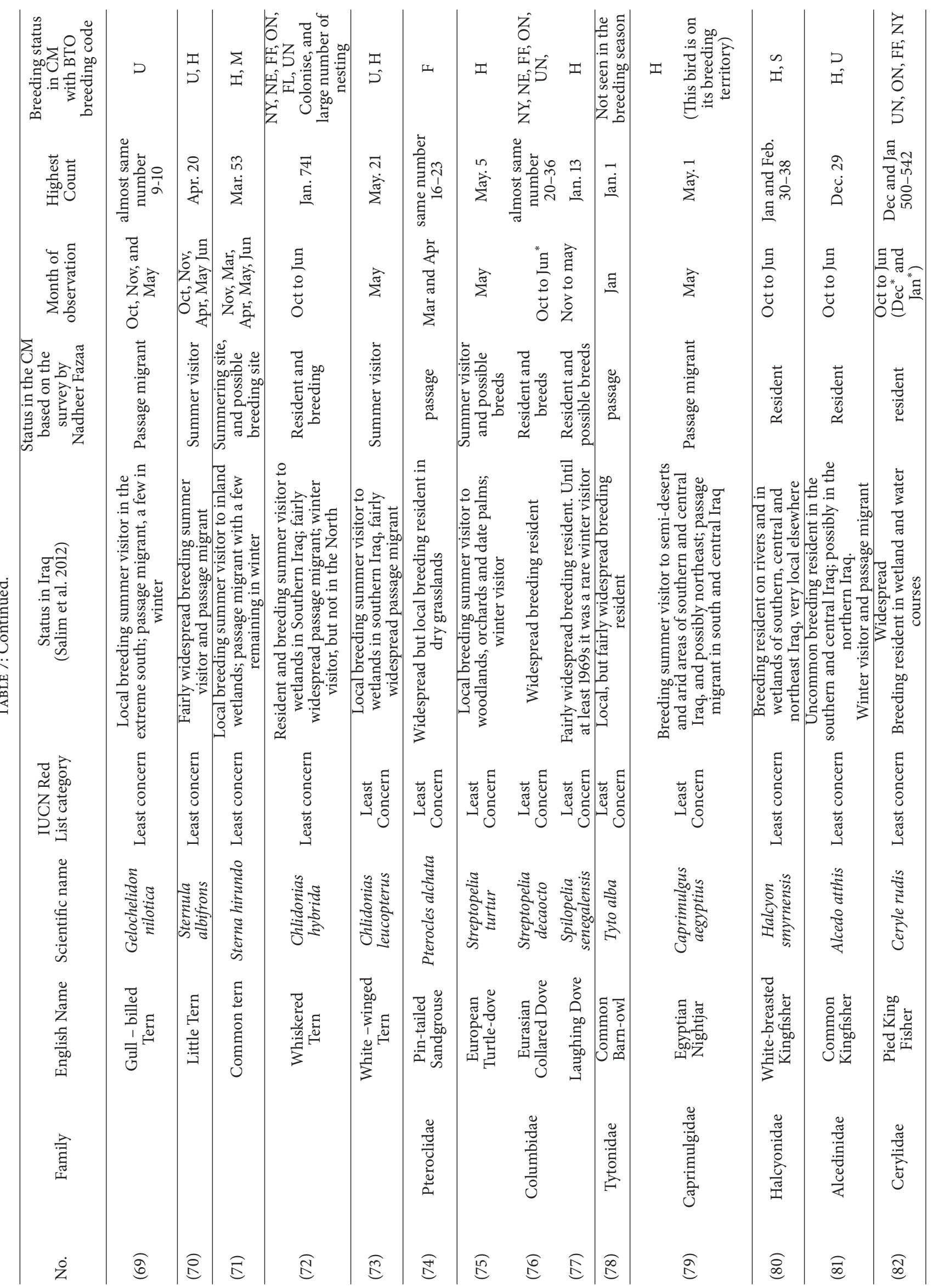




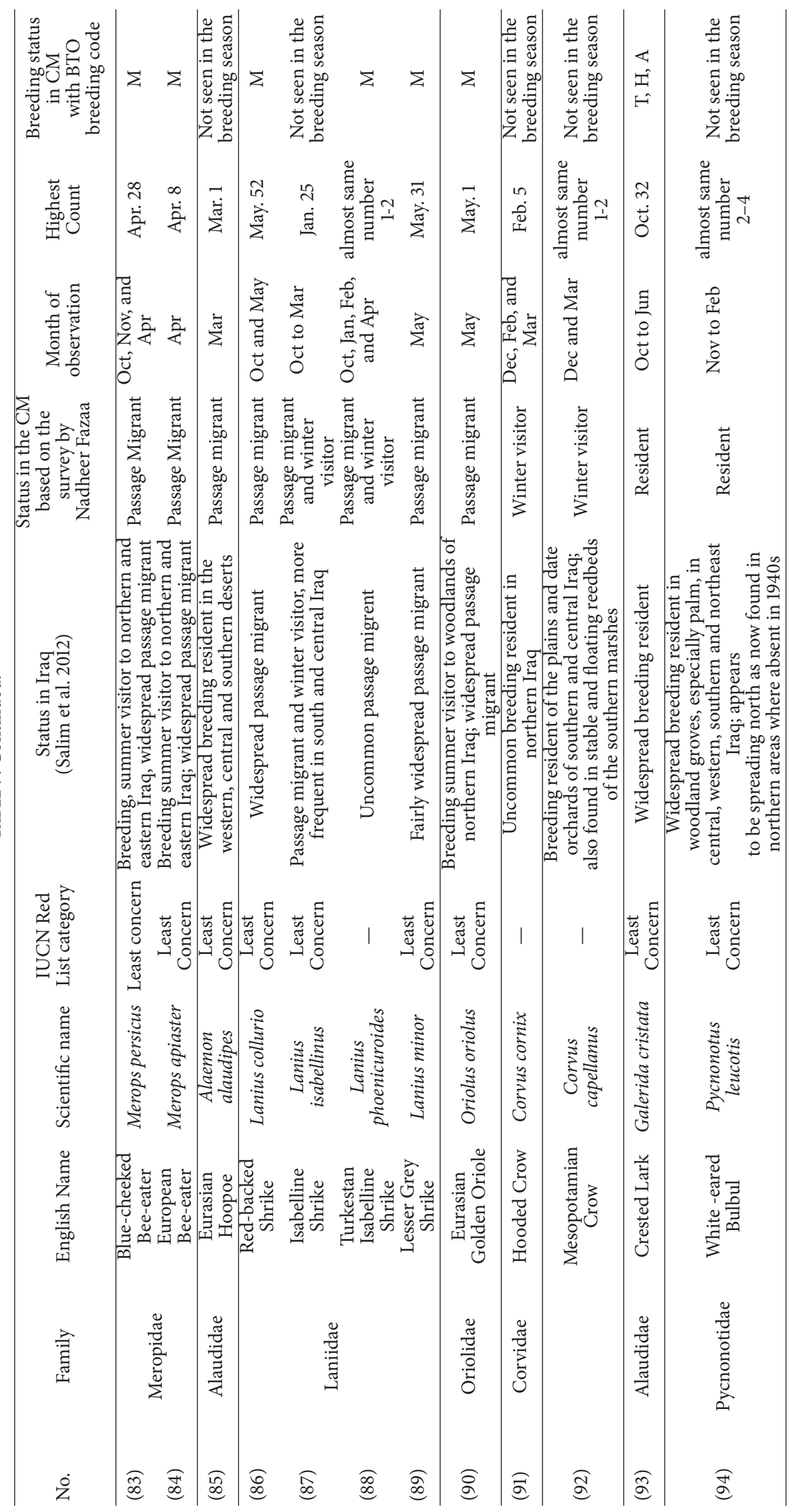




\begin{tabular}{|c|c|c|c|c|c|c|c|c|c|c|c|c|}
\hline 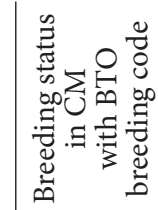 & $\begin{array}{l}D \\
\hat{I}\end{array}$ & $\begin{array}{l}\text { I } \\
\hat{H} \\
\infty \\
\tilde{z} \\
0\end{array}$ & $\Sigma$ & 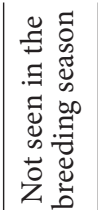 & 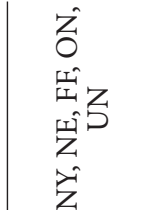 & $\begin{array}{l}z \\
\vdots \\
z \\
0 \\
0 \\
y \\
z\end{array}$ & $\Sigma$ & $\begin{array}{l}I \\
\sum\end{array}$ & $\begin{array}{l}n \\
\hat{H} \\
\hat{n} \\
\hat{z} \\
0 \\
\hat{z} \\
0 \\
0\end{array}$ & $\begin{array}{l}I \\
\omega^{-} \\
z \\
0\end{array}$ & $\begin{array}{l}\text { I } \\
\text { S }\end{array}$ & 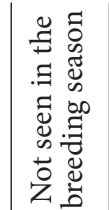 \\
\hline 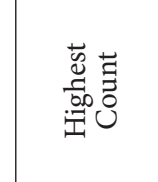 & $\begin{array}{l}\text { H } \\
\ddot{0} \\
\dot{\overrightarrow{4}}\end{array}$ & 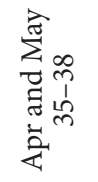 & $\overrightarrow{\ddot{4}}$ & 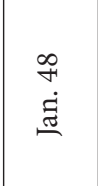 & $\begin{array}{l}\stackrel{8}{0} \\
\Xi \\
\dot{\Xi}\end{array}$ & $\begin{array}{l}\text { in } \\
\text { 离 }\end{array}$ & 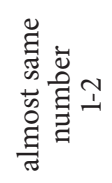 & 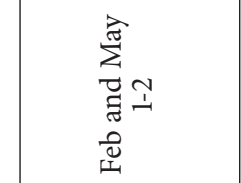 & 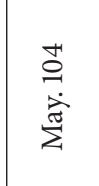 & $\begin{array}{l}\infty \\
i n \\
\stackrel{\vec{z}}{\mathbf{z}}\end{array}$ & 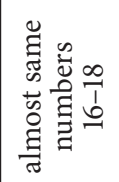 & $\begin{array}{l}\text { के } \\
\text { हn } \\
\text { कें }\end{array}$ \\
\hline 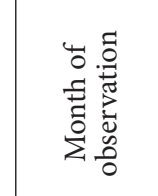 & 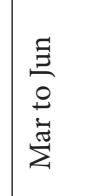 & 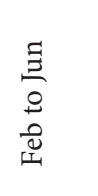 & 荌 & $\begin{array}{l}\text { 㟯 } \\
0 \\
0 \\
0 \\
z\end{array}$ & 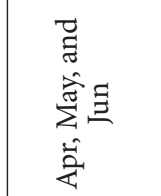 & 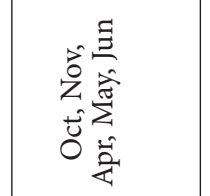 & 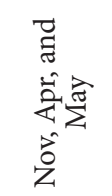 & 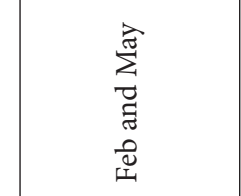 & $\frac{\Xi}{\frac{\Xi}{0}}$ & $\frac{\Xi}{\Xi}$ & 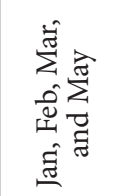 & $\begin{array}{l}\sum_{n}^{\pi} \\
0 \\
0 \\
z \\
z\end{array}$ \\
\hline 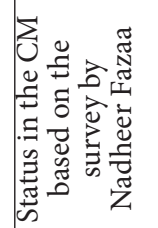 & 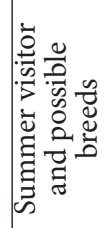 & 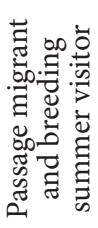 & 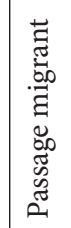 & 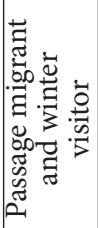 & 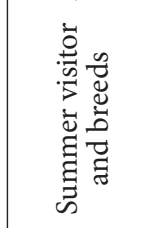 & 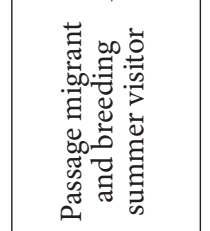 & 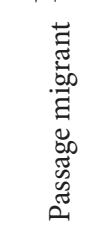 & 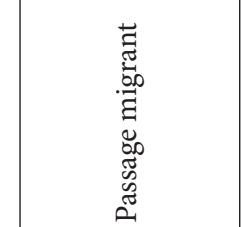 & 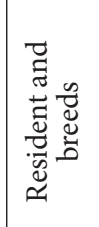 & 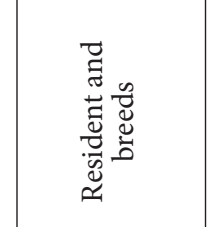 & 节 & 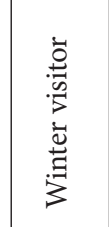 \\
\hline 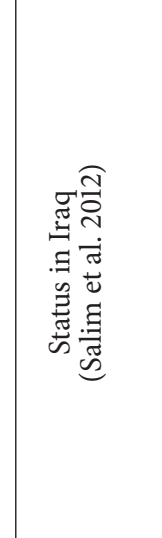 & 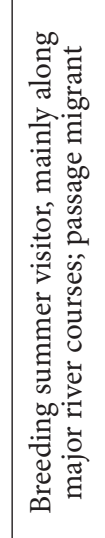 & 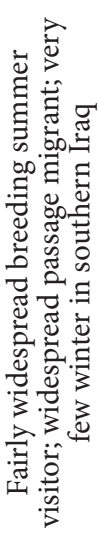 & 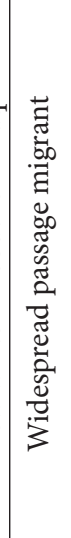 & 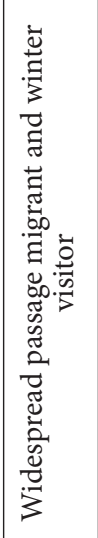 & 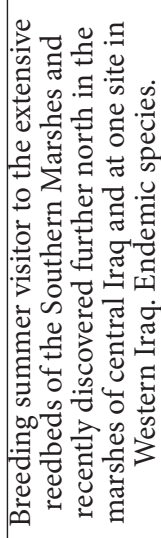 & 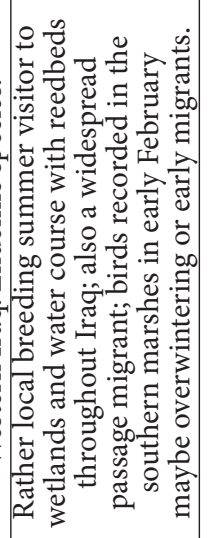 & 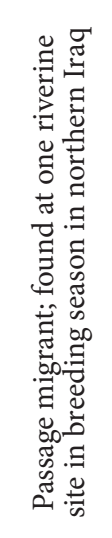 & 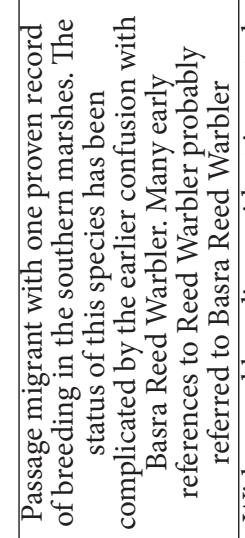 & 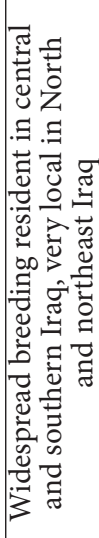 & 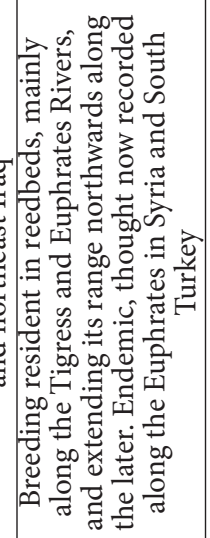 & 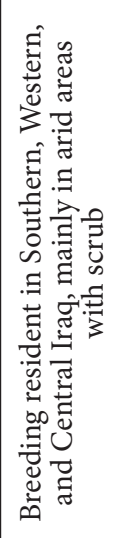 & 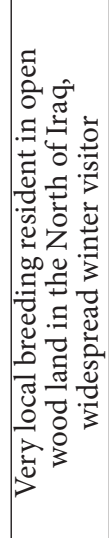 \\
\hline 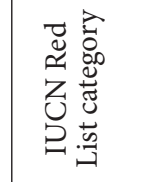 & 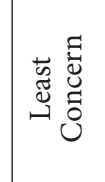 & 范 & 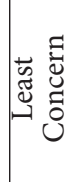 & 焉 & 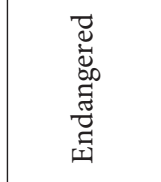 & 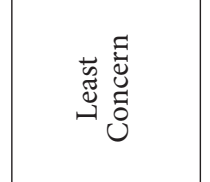 & 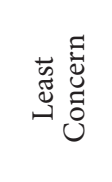 & 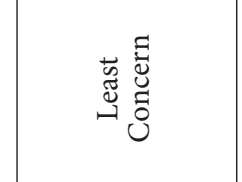 & 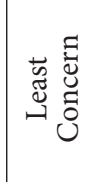 & 菢 & 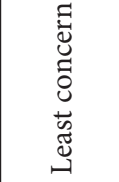 & 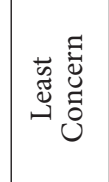 \\
\hline 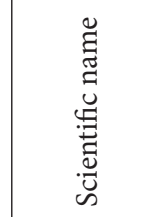 & 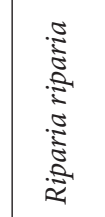 & 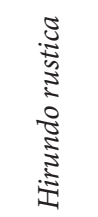 & 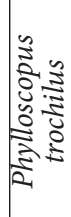 & 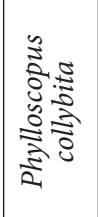 & 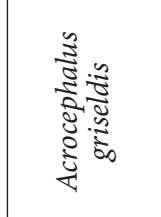 & 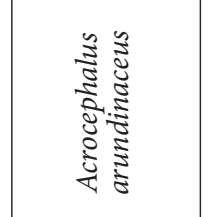 & 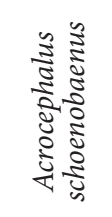 & 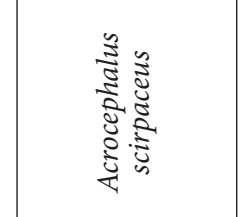 & 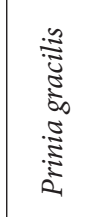 & 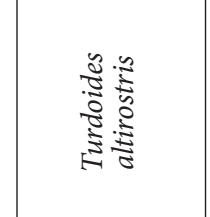 & 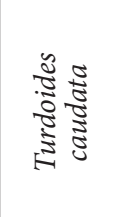 & 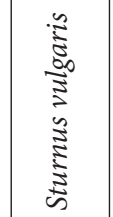 \\
\hline 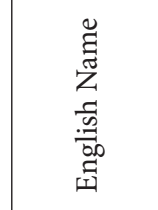 & 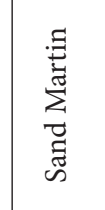 & 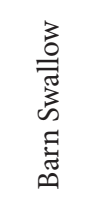 & 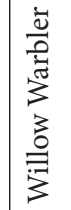 & 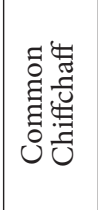 & 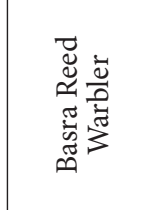 & 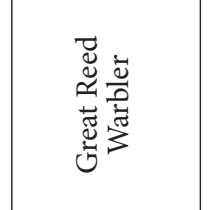 & 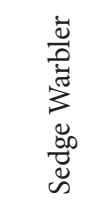 & 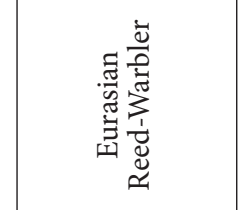 & 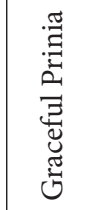 & 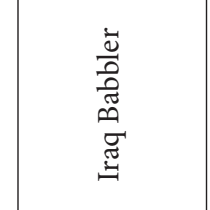 & 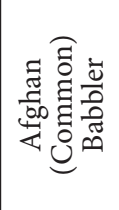 & 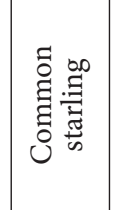 \\
\hline 佘 & & 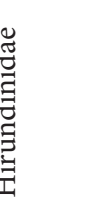 & 童 & 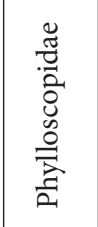 & 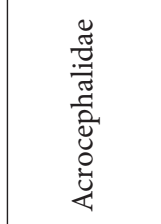 & & $\frac{\stackrel{\tilde{J}}{0}}{\frac{5}{2}}$ & & 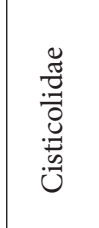 & 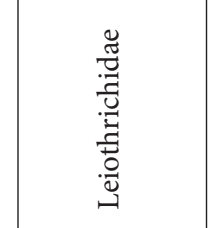 & & $\tilde{z}$ \\
\hline$\dot{z}$ & ハू & ஜ & 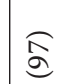 & 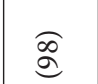 & $\widehat{\sigma}$ & 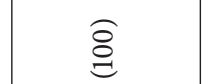 & $\overrightarrow{\widetilde{g}}$ & త్ర & e्g & ج্이 & 危 & 8 \\
\hline
\end{tabular}




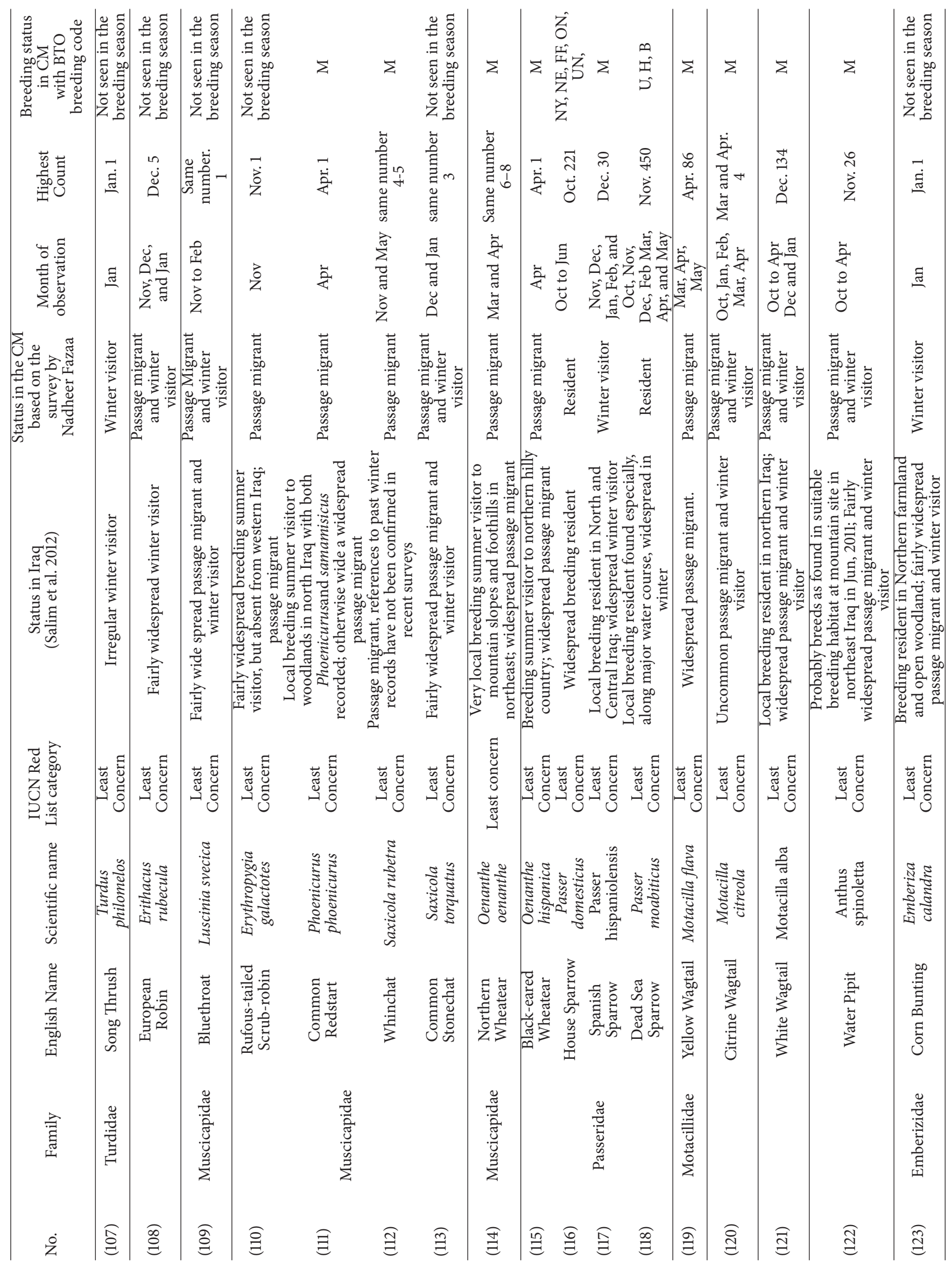




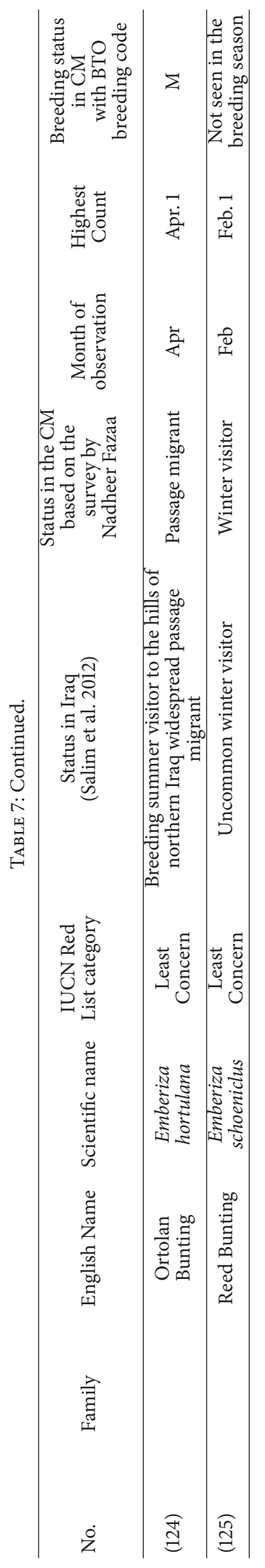


CM, which could help form the basis of a management plan for their conservation.

We make the following recommendations for management and future work relating to bird conservation in the CM:

(1) Limit local human activities in zone one and support the designation of zone one as a buffer for zones 2 and 3.

(2) Future bird monitoring studies should repeat our methods, although if possible, the direction of survey (north-south versus south-north) should be randomized.

(3) Ensure that water levels in the Euphrates River are maintained because this is the main source for CM's water during summer and winter and is needed for bird populations.

(4) Following the establishment of a soil embankment between Chibayish City in Nasiriyah Province and Modina City in Basra Province, we recommend detailed analysis of water quality and sediments to evaluate the concentration of pesticides and heavy metals and their effects on bird species and other fauna in the CM.

(5) Evaluate local threats (e.g., hunting) and global potential threats (e.g., climate change) on the CM as a site and bird species in the area.

(6) Extend our findings on key species, for example, Basra Reed Warbler, to provide more precise estimates of population sizes within the CM.

\section{Appendix}

See Tables 4-7.

\section{Disclosure}

This work is part of a Ph.D. programme supported by the College of Sciences for Women, University of Baghdad, Iraqi Ministry of Higher Education and Scientific Research, under Scholarship no. 33258 .

\section{Competing Interests}

The authors declare that they have no competing interests.

\section{Acknowledgments}

The authors thank the Iraqi Ministry of Environment, Nature Iraq, and Iraqi Green Climate Organization for supporting the field work. This work could not be done without technical support that was provided by Mudhafar Salim and Richard Porter. The authors thank Richard Porter and Mike Evans from Birdlife International for reviewing the data. The authors thank Laith Ali for participating in two of nine field surveys and Omar Al Sheikhly for help in identifying some bird species.

\section{References}

[1] C. J. Richardson and N. A. Hussain, "Restoring the garden of eden: an ecological assessment of the marshes of Iraq," BioScience, vol. 56, no. 6, pp. 477-489, 2006.

[2] C. Rubec, A. Alwash, and A. Bachmann, "The key biodiversity areas project in Iraq: objectives and scope 2004-2008," BioRisk, vol. 3, pp. 39-53, 2009.

[3] M. I. Evans, Important Bird Areas in the Middle East, Birdlife International, Cambridge, UK, 1994.

[4] Nature Iraq, Draft of the Key Biodiversity Area Inventory for Iraq, Nature Iraq, 2013, http://www.natureiraq.org/draftinventory-of-sites.html.

[5] E. Maltby, "An environmental and ecological study of the marshlands of mesopotamia," Draft Consultative Bulletin, AMAR Appeal Trust, 1994.

[6] M. I. Evans, "The ecosystem," in The Iraqi Marshlands: A Human and Environmental Study, E. Nicholson and P. Clark, Eds., pp. 201-219, Politico's Publishing, London, UK, 2002.

[7] A. Alwash, G. Gali, N. A. Fazaa, and A. Sopelsa, "The Mesopotamia Marshlands National Park planning process," in Proceedings of the Conference of College of Science, Baghdad University, Baghdad, Iraq, 2009.

[8] M. Spencer, The Marsh Arabs Revisited, Saudi Aramco World, 1982.

[9] C. J. Richardson, P. Reiss, N. A. Hussain, A. J. Alwash, and D. J. Pool, "The restoration potential of the Mesopotamian marshes of Iraq," Science, vol. 307, no. 5713, pp. 1307-1311, 2005.

[10] M. Salim, R. Porter, and C. Rubec, "A summary of birds recorded in the marshes of southern Iraq, 2005-2008," BioRisk, vol. 3, pp. 205-219, 2009.

[11] Iraqi Ministries, "New Eden master plan for the integrated water resources management in the Marshland area, Main Report, Iraqi Ministries of Environment," Water Resources Municipalities and Public Works with Cooperation of the Italian Ministry for the Environment and Territory and Free Iraq Foundation 20, 2006.

[12] F. Pearce, "Garden of Eden to be protected as Iraqi national park," New Scientist, vol. 219, no. 2928, 11 pages, 2013.

[13] IMOE, Fifith National Report to the Convention of Biological Diversity, 2014, http://www.cbd.int/kb/Results?q=IRAQ.

[14] W. J. Sutherland, Ecological census techniques, Cambridge University Press, 2006.

[15] K. P. Burnham and D. R. Anderson, Model Selection and Multimodel Inference: A Practical Information-Theoretic Approach, Springer, Berlin, Germany, 2nd edition, 2002.

[16] C. E. Grueber, S. Nakagawa, R. J. Laws, and I. G. Jamieson, "Multimodel inference in ecology and evolution: challenges and solutions," Journal of Evolutionary Biology, vol. 24, no. 4, pp. 699-711, 2011.

[17] K. Barton, Model Selection and Model Averaging Based on Information Criteria (AICc and alike), Version 3.2.5, R Package, 2011, http://cran.r-project.org/web/packages/MuMIn/index.html.

[18] O. F. Al-Sheikhly, I. Nader, and F. Barbanera, "Breeding ecology of the Basra Reed Warbler, Acrocephalus griseldis, in Iraq (Aves: Passeriformes: Acrocephalidae)," Zoology in the Middle East, vol. 59, no. 2, pp. 107-117, 2013.

[19] O. F. Al-Sheikhly, I. Nader, F. Barbanera et al., "A response to the comment of Porter et al. (2014) on 'breeding ecology of the Basra Reed Warbler Acrocephalus griseldis (Hartlaub, 1891) in Iraq (Aves: Passeriformes: Acrocephalidae)"', Zoology in the Middle East, vol. 61, no. 2, pp. 193-199, 2015. 
[20] M. Salim, O. Al-Sheikhly, K. Majeed, and R. Porter, "An annotated checklist of the birds of Iraq," Sangrouse, vol. 34, no. 1, pp. 4-43, 2012.

[21] M. A. Salim and R. F. Porter, "The ornithological importance of the southern marshes of Iraq," Marsh Bulletin, vol. 10, no. 1, pp. 1-24, 2015.

[22] A. Symes, J. Taylor, D. Mallon, R. Porter, C. Simms, and K. Budd, The Conservation Status and Distribution of the Breeding Birds of the Arabian Peninsula, 2015, http://www.iucnredlist.org/.

[23] R. Porter, L. Batten, J. Burton et al., "Towards a better understanding of Basra Reed Warbler Acrocephalus griseldis (Aves: Passeriformes: Acrocephalidae) ecology? a comment on AlSheikhly et al. (2013)," Zoology in the Middle East, vol. 61, no. 2, pp. 190-192, 2015. 

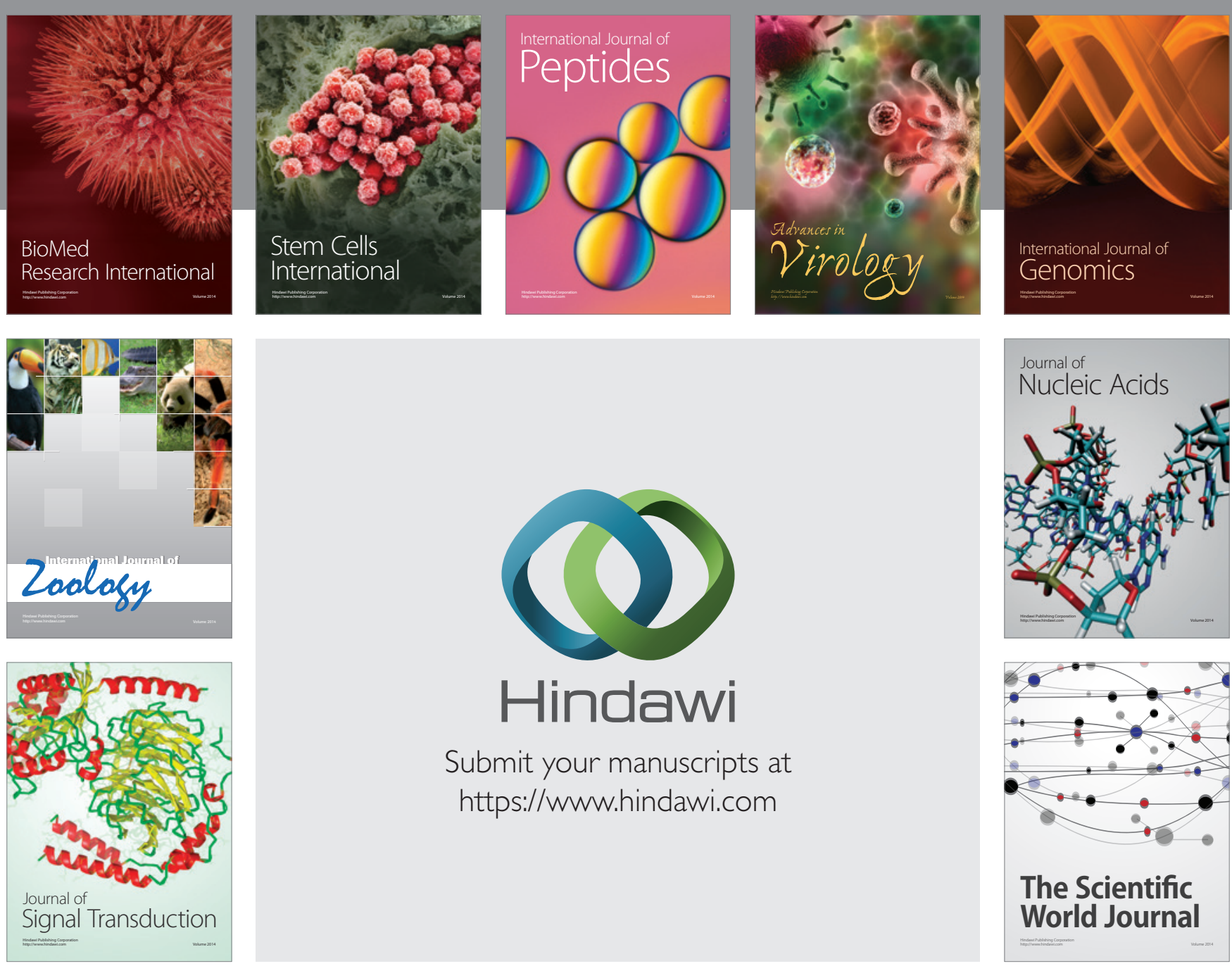

Submit your manuscripts at

https://www.hindawi.com
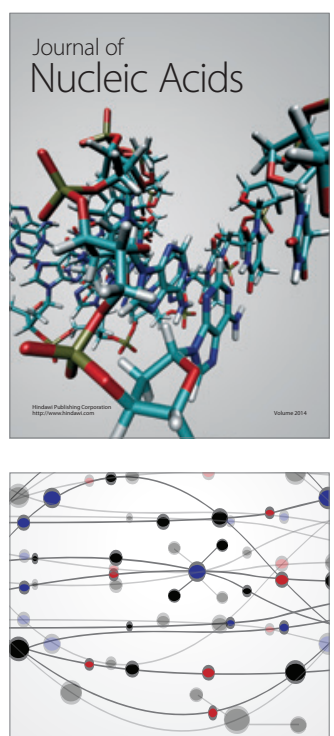

The Scientific World Journal
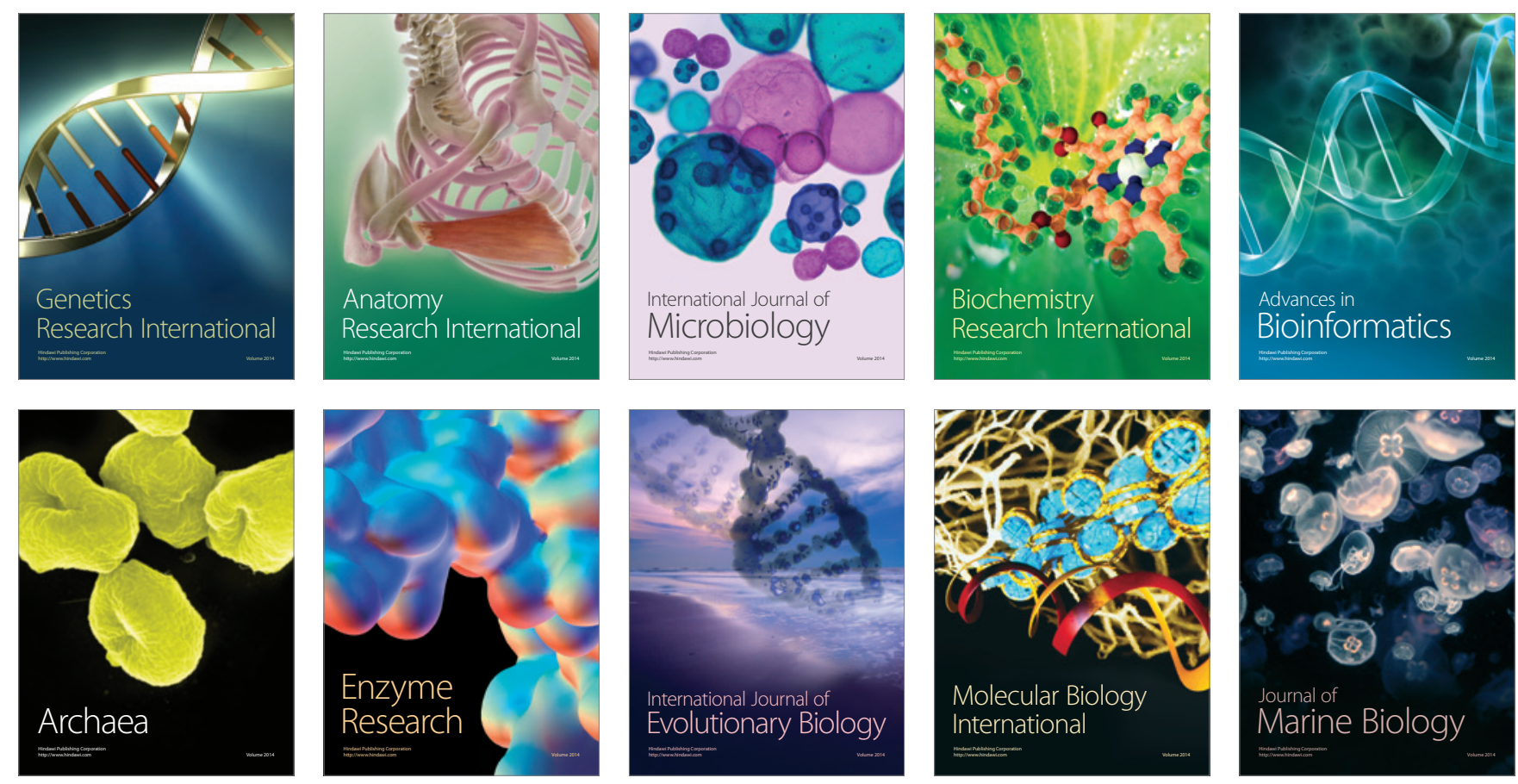